\title{
Nitrate fate and transport through current and former depressional wetlands in an agricultural landscape, Choptank Watershed, Maryland, United States
}

\author{
J.M. Denver, S.W. Ator, M.W. Lang, T.R. Fisher, A.B. Gustafson, R. Fox, J.W. Clune, and G.W. McCarty
}

\begin{abstract}
Understanding local groundwater hydrology and geochemistry is critical for evaluating the effectiveness of wetlands at mitigating agricultural impacts on surface waters. The effectiveness of depressional wetlands at mitigating nitrate $\left(\mathrm{NO}_{3}\right)$ transport from fertilized row crops, through groundwater, to local streams was examined in the watershed of the upper Choptank River, a tributary of Chesapeake Bay on the Atlantic Coastal Plain. Hydrologic, geochemical, and water quality data were collected from January of 2008 through December of 2009 from surface waters and networks of piezometers installed in and around current or former depressional wetlands of three major types along a gradient of anthropogenic alteration: (1) natural wetlands with native vegetation (i.e., forested); (2) prior-converted croplands, which are former wetlands located in cultivated fields; and (3) hydrologically restored wetlands, including one wetland restoration and one shallow water management area. These data were collected to estimate the orientation of groundwater flow paths and likely interactions of groundwater containing $\mathrm{NO}_{3}$ from agricultural sources with reducing conditions associated with wetlands of different types. Natural wetlands were found to have longer periods of soil saturation and reducing conditions conducive to denitrification compared to the other wetland types studied. Because natural wetlands are typically located in groundwater recharge areas along watershed divides, nitrogen $(\mathrm{N})$ from nearby agriculture was not intercepted. However, these wetlands likely improve water quality in adjacent streams via dilution. Soil and geochemical conditions conducive to denitrification were also present in restored wetlands and prior-converted croplands, and substantial losses of agricultural $\mathrm{NO}_{3}$ were observed in groundwater flowing through these wetland sediments. However, delivery of $\mathrm{NO}_{3}$ from agricultural areas through groundwater to these wetlands resulting in opportunities for denitrification were limited, particularly where reducing conditions did not extend throughout the entire thickness of the surficial aquifer allowing $\mathrm{NO}_{3}$ to pass conservatively beneath a wetland along deeper groundwater flow paths. The complexity of $\mathrm{N}$ fate and transport associated with depressional wetlands complicates the understanding of their importance to water quality in adjacent streams. Although depressional wetlands often contribute low $\mathrm{NO}_{3}$ water to local streams, their effectiveness as landscape sinks, for $\mathrm{N}$ from adjacent agriculture varies with natural conditions, such as the thickness of the aquifer and the extent of reducing conditions. Measurement of such natural geologic, hydrologic, and geochemical conditions are therefore fundamental to understanding $\mathrm{N}$ mitigation in individual wetlands.
\end{abstract}

Key words: agriculture-Chesapeake Bay-denitrification-depressional wetlandsgroundwater-wetland conservation practices

Local hydrologic and geochemical conditions control the movement of nitrate (NO) through and around depressional wetlands and, therefore, the effective- ness of those wetlands as landscape sinks for nitrogen $(\mathrm{N})$ from nearby agriculture. Nitrogen occurs widely in the form of $\mathrm{NO}_{3}$ in groundwater which is an impor- tant vector for agricultural $\mathrm{N}$ transport to many streams and tidal waters (Staver and Brinsfield 1996; Böhlke 2002; Phillips and Lindsey 2003; Nolan and Hitt 2006; Spruill and Bratton 2008). Ator and Denver (2012) estimated that $70 \%$ of the $\mathrm{N}$ load to surface water in the Chesapeake Bay watershed on the Delmarva Peninsula moves through groundwater. Reducing conditions and abundant organic matter typical of wetlands promote removal of $\mathrm{NO}_{3}$ through denitrification and may thus improve groundwater quality (Howarth et al. 1996; Whigham and Jordan 2003). Denitrification occurs where groundwater containing $\mathrm{NO}_{3}$ passes through any sufficiently reducing environment (Puckett 2004) and has been observed in riparian and hyporheic sediments (Kennedy et al. 2009), and along upgradient groundwater flow paths (Tesoriero et al. 2000; Spruill et al 2005; Böhlke et al. 2007; Mehnert et al. 2007; Denver et al. 2010), as well as in wetland sediments (Puckett 2004; Whigham and Jordan 2003).

The effectiveness of wetlands for mitigating agricultural $\mathrm{NO}_{3}$ depends primarily on local hydrology and the movement of water through the landscape, which controls how much $\mathrm{NO}_{3}$ actually passes through the zone of wetland influence (Puckett 2004; Tesoriero et al. 2009). Shallow groundwater flow systems around wetlands and other surface water bodies are commonly transient and complex and reflect influences of local geology, variable precipitation and recharge, and groundwater flow systems at local to regional scales (Winter 1983, 1999). Groundwater, for example, moves laterally just beneath the water table and through shallow riparian zone sediments only when restricted to a particularly thin unconfined aquifer; in thicker unconfined aquifers, $\mathrm{NO}_{3}$

Judy Denver is a hydrologist at the US Geological Survey in Dover, Delaware. Scott Ator is a hydrologist at the US Geological Survey in Baltimore, Maryland. Megan Lang is a research ecologist at the US Forest Service Northern Research Station in Beltsville, Maryland. Tom Fisher is a professor, Anne Gustafson is a research assistant, and Rebecca Fox is an assistant research scientist at the Horn Point Laboratory, University of Maryland Center for Environmental Science, Cambridge, MD. John Clune is a hydrologist at the US Geological Survey in Dover, Delaware. Greg McCarty is a Research Soils Scientist at the USDA ARS Hydrology and Remote Sensing Laboratory in Beltsville, Maryland. 
is also delivered to streams along flow paths at depths beneath the influence of riparian forests or wetlands (Böhlke and Denver 1995; Hill 1996; Puckett 2004; Ator et al. 2005a). Where depressional wetlands collect rainfall and surface runoff, focused recharge may cause reversals in shallow groundwater flow, and wetlands may alternately provide recharge to or receive discharge from adjacent shallow groundwater within relatively short time periods (Winter 1983; Phillips and Shedlock 1993; Leibowitz and Nadeau 2003). Wetlands on slopes or in discharge areas may receive groundwater from some distant upgradient, while those in groundwater recharge areas may only receive flow from very local areas (Winter 1983; 1999; Phillips et al. 1993).

Nitrogen transformations in wetlands vary spatially and temporally in response to variability in interacting hydrologic and geochemical characteristics that are often undocumented (Howarth et al. 1996, Whigham and Jordan 2003). For example, limited observations of nutrient concentrations and redox potential or excess $\mathrm{N}$ gas just beneath the water table at the edge of a field or beneath a stream (Kennedy et al. 2009) can be effective for estimating net local denitrification, but misleading regarding the specific location or spatial extent of the denitrifying conditions (Puckett 2004). Furthermore, such measurements provide little insight into the three-dimensional nature of groundwater flow necessary to understand $\mathrm{NO}_{3}$ movement and estimate $\mathrm{NO}_{3}$ losses in order to calculate ecosystem service benefits. Extrapolating observations of wetland effectiveness from local studies to regional areas is particularly difficult (Howarth et al. 1996) and greatly benefits from a comprehensive understanding of $\mathrm{NO}_{3}$ fate and transport provided by direct hydrologic and geochemical observations.

This paper compares and contrasts hydrologic and geochemical conditions and the resulting fate and transport of $\mathrm{NO}_{3}$, the major $\mathrm{N}$ species found in groundwater, in and around palustrine nonriparian depressional wetlands (henceforth referred to as depressional wetlands) along an anthropogenic alteration gradient within an agricultural landscape. Three major types of depressional wetlands were studied: (1) natural wetlands with native vegetation located in forested areas; (2) prior-converted croplands, which are former wetlands located in cultivated areas; and (3) hydrologically restored wetlands, including one wetland restoration and one shallow water management area. Although water quality has been investigated previously around numerous riparian wetlands, similar studies of depressional wetlands are less common (Whigham and Jordan 2003). Leibowitz and Nadeau (2003) noted a relative lack of water quality studies related to isolated wetlands, which are usually depressional, and emphasized the need for additional studies on the importance of isolated wetlands to regional water quality. We hypothesize that the effectiveness of depressional wetlands at mitigating $\mathrm{NO}_{3}$ varies with local hydrologic conditions and site management. The importance of three-dimensional hydrology and collection of a broader suite of geochemical indicators than are commonly collected for the interpretation of $\mathrm{NO}_{3}$ loss in wetlands is discussed.

\section{Materials and Methods}

Study Area. The Choptank River drains the central Delmarva Peninsula in Maryland and Delaware and has the largest nontidal watershed that flows from the peninsula to the Chesapeake Bay (figure 1). The watershed is rural, and land use is dominated by agriculture $(60 \%$; production of corn [Zea mays L.], soybean [Glycine max L.], and small grain crops), with smaller amounts of forest (33\%) and urban/suburban areas (7\%) (McCarty et al. 2008; Fisher et al. 2010). Poultry production is common; more than one million broiler chickens were produced in the watershed in 1997 (Sprague et al. 2000). Agricultural applications (primarily fertilizer and manure) are estimated to represent more than $70 \%$ of $\mathrm{N}$ sources in the watershed; relatively minor $\mathrm{N}$ sources in the watershed include septic systems and isolated urban areas (Sprague et al. 2000).

Much of the upper Choptank Watershed is generally flat and poorly drained, with low water table gradients (Shedlock et al 1999). Tracts of forested wetlands are interspersed with agricultural fields. Depressional wetlands are relatively abundant and are often characterized as Delmarva Bays (figure 2), which are believed to have formed from freezing and thawing related to the cold climate during the last glacial period (Newell and Dejong 2011; Owens and Minard 1979). Soils range from very poorly drained mucks with high organic matter content in depressions to well-drained sandy loams beneath farm fields. Most of the depressional wetlands were historically isolated from surface-water drainage. However, artificial ditches originally installed to improve drainage for cultivation or mosquito abatement now connect many of the watershed's depressional wetlands to surface waters (Lang et al. 2012). Cropland occupies most areas where soil could be adequately drained, and prior-converted croplands are common in fields. Prior-converted croplands are defined by the USDA Natural Resource Conservation Service (NRCS) as wetlands that were manipulated (drained or otherwise physically altered to remove excess water from the land with wetland hydrology for less than two weeks out of the growing season) and cropped prior to December 23, 1985 (Kirchner et al. 1992). Attempts to drain much of the area that is currently forested, however, were unsuccessful, although ditches remain in many forested areas. Ditches are very common features in Coastal Plain agricultural watersheds. During periods of low evapotranspiration, usually in the winter, these ditches carry water from wetlands to local streams.

Hydrologic conditions in the Choptank Watershed are generally typical of the central Delmarva Peninsula (Shedlock et al. 1999) and parts of the wider mid-Atlantic Coastal Plain (Ator et al. 2005b). The area is blanketed by an unconfined surficial aquifer that formed from sediments deposited from the outwash of continental glaciers to the north (Owens and Minard 1979). The aquifer is relatively

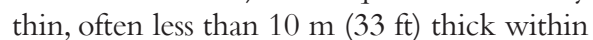
the study area. Groundwater generally follows relatively short flowpaths from local uplands to discharge areas in nearby streams. On the Delmarva Peninsula, the residence time of groundwater in the surficial aquifer seldom exceeds a few decades (Dunkle et al. 1993; Böhlke and Denver 1995).

Abundant wetlands and other potential $\mathrm{NO}_{3}$ sinks affect water quality in the Choptank River. For example, a large subwatershed $\left(292 \mathrm{~km}^{2}\right.$ [113 $\left.\left.\mathrm{mi}^{2}\right]\right)$ of the Choptank River that includes this study area contains numerous wetlands and abundant poorly drained soils exports only $14 \%$ of applied N, which is significantly less than the percent of $\mathrm{N}$ exported from well-drained portions of the Choptank Watershed (Fisher et al. 1998; Sprague et al. 2000; Brakebill and Preston 2004). Previous estimates of the proportion of $\mathrm{N}$ delivered to the river as groundwater 


\section{Figure 1}

Location of the upper Choptank Watershed and general location of the study area.

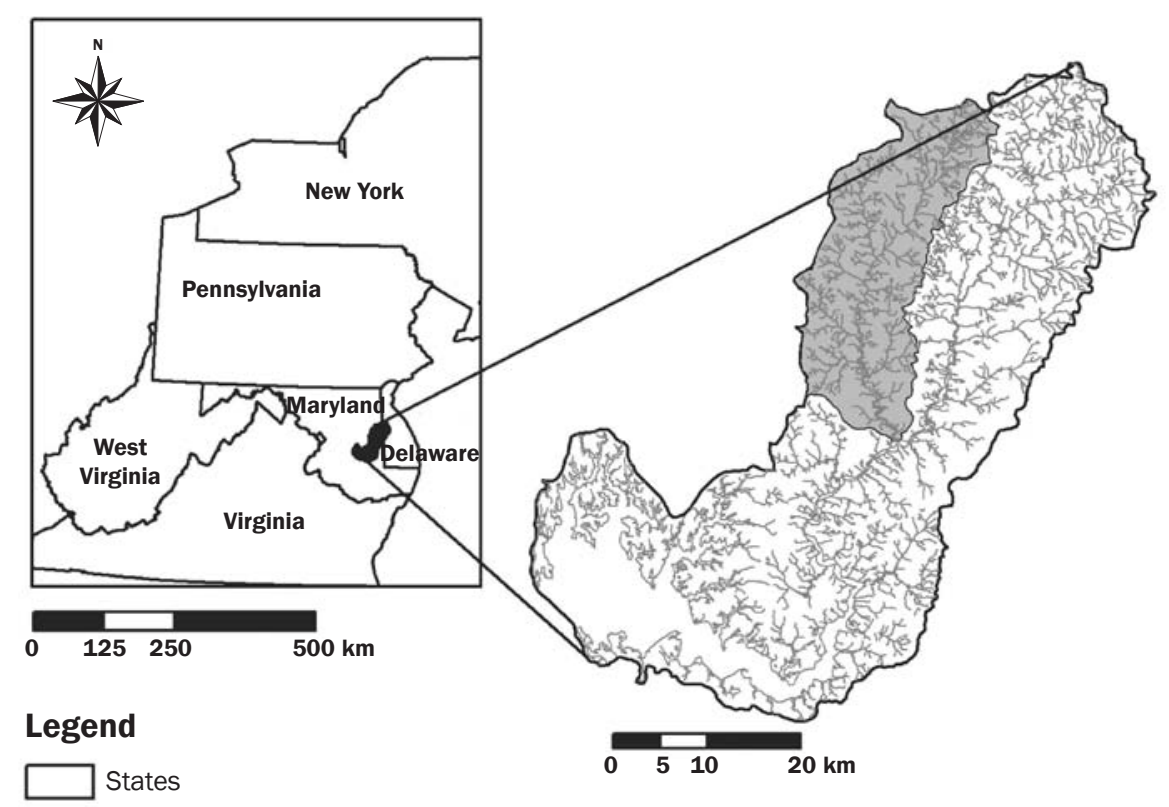

Legend

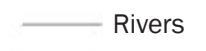

Study site

\section{Figure 2}

(a) A photograph taken on December 24, 2007, shows that the land surface of the upper Choptank has numerous nonriparian depressions that function as wetlands. (b) Elevation data collected on March 27, 2007, using light detection and ranging (LiDAR), shows the extent of the depressions in this area. Examples of depressional wetlands are outlined with dashed lines. (a)

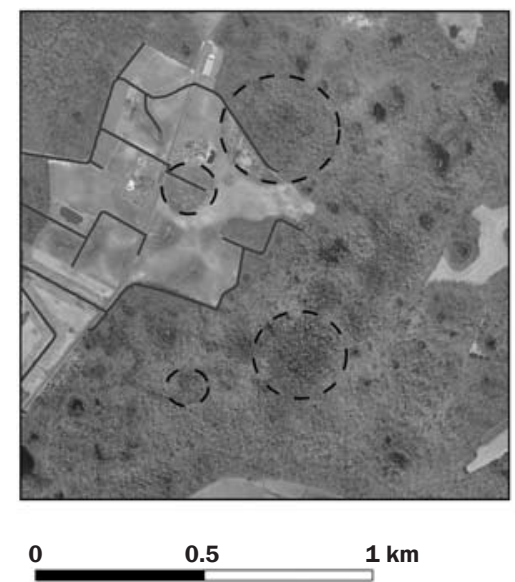

(b)

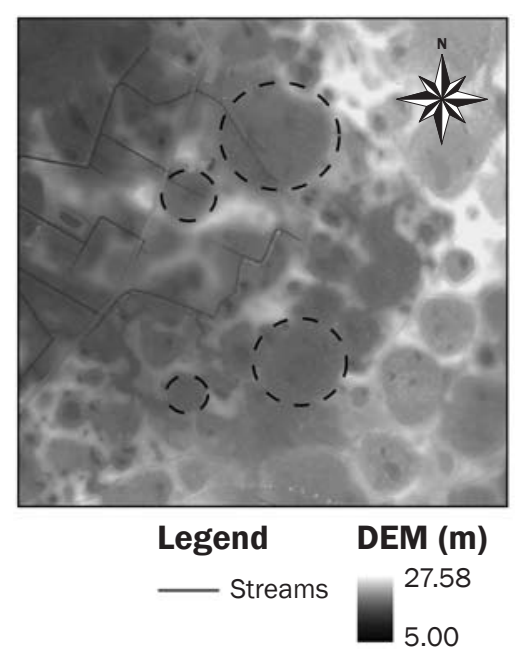

$\mathrm{NO}_{3}$ vary from $43 \%$ to $64 \%$ (Bachman et al. 1998; Sprague et al. 2000).

Selection of Wetland Study Sites. Natural, prior-converted, and restored wetlands within the upper Choptank Watershed were selected for study to provide insight on natural hydrologic and geochemical variability affecting $\mathrm{NO}_{3}$ fate and transport under each management scenario (figure 3 ). The study sites were replicated in the natural and priorconverted cropland sites, and two different types of wetland conservation practices were studied as restored sites. Hydrology at the natural, prior-converted cropland, and one of the restored sites was influenced by bisecting or adjacent ditches. Individual sites were selected for study on the basis of local conditions and land-owner cooperation. Specific locations were omitted from this paper out of respect for land-owner privacy in accordance with USDA policies.

Geologic Investigations. Shallow subsurface investigations were conducted at each site to evaluate the geologic setting. A continuous core to the first major confining unit, generally within 6 to $10 \mathrm{~m}$ (20 to $33 \mathrm{ft}$ ) of the land surface, was collected from at least one location at each site and used to estimate the local thickness, permeability, and general redox state (based on sediment color) of the surficial unconfined aquifer. Transects were established based on topography along a presumed hydraulic gradient from adjacent uplands into each wetland, and soil samples were collected by hand auger to shallow (i.e., a few meters or less) depths at several locations along each transect. Soil sampling was conducted during a particularly dry period from September of 2007 through November of 2007, which improved access to wetland sites.

Description of Natural Wetland Study Sites. These sites are forested and were located in upland landscapes near watershed divides that serve as recharge areas for the surficial aquifer in areas where historical drainage efforts were unsuccessful (figures 3 and 4). Soil characteristics ranged from very poorly drained organic mucks beneath depressions to poor and moderately well drained sandy loams on the surrounding flats (USDA NRCS 2006a). Clay and silt layers from $0.5 \mathrm{~m}(1.6 \mathrm{ft})$ to more than $2 \mathrm{~m}(6.6$ $\mathrm{ft}$ ) in thickness were common beneath the depressions and were noted in local cores.

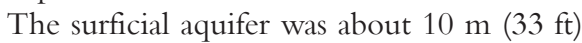
thick beneath natural site 1 (NAT1) and $6 \mathrm{~m}$ 


\section{Figure 3}

Aerial photographs of study sites and general location of piezometer transects at the natural (a) NAT1 and (b) NAT2 sites, prior-converted cropland (c) PCC1 and (d) PCC2 sites, and restored (e) RES1 and (f) RES2 study sites. Dashed lines indicate location of depressional wetlands, circular symbols indicate locations of shallow piezometers, and triangular symbols represent locations of deeper groundwater samples collected using a Geoprobe. All photographs were taken on December 24, 2007, as described by Lang and McCarty (2009).

(a)

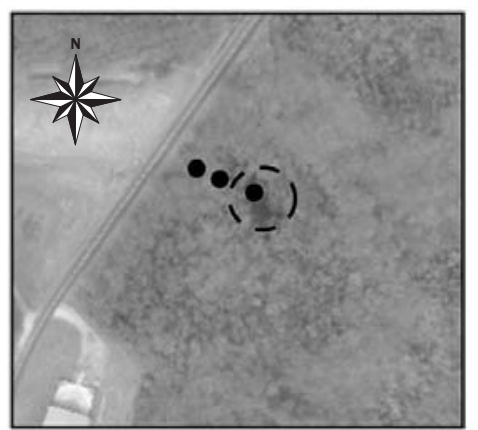

(d)

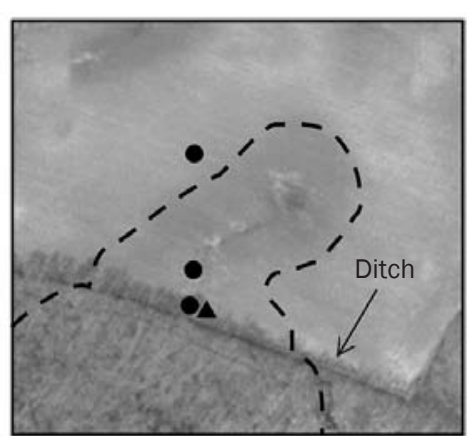

(b)

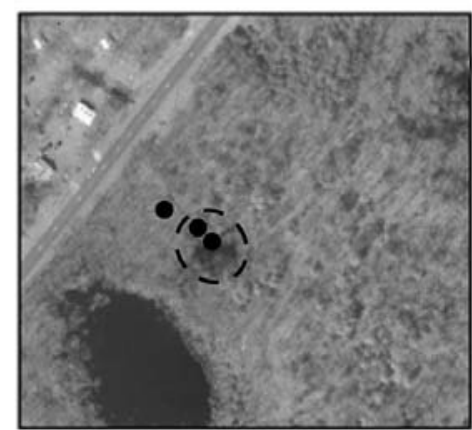

(e)

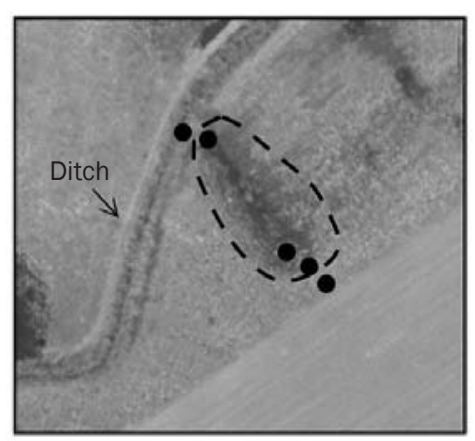

(c)

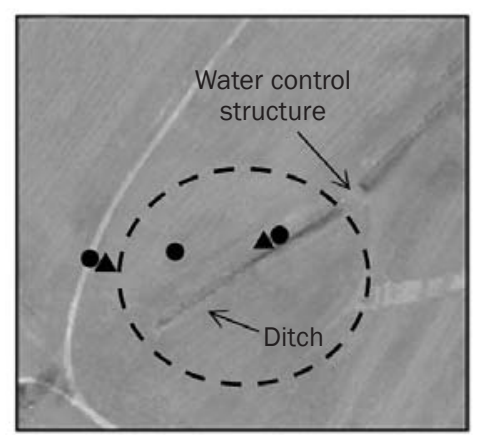

(f)

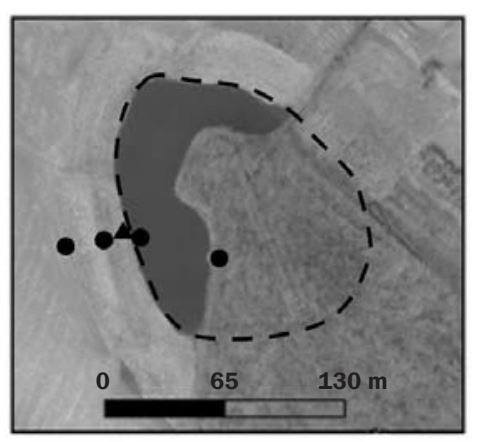

(20 ft) thick beneath natural site 2 (NAT2). Most of the aquifer sediments in cores were gray in color, indicating primarily anoxic conditions. Sediment color was mottled orange and gray with bands of iron staining near the surface in and near depressions, suggesting variable redox conditions associated with frequent wetting and drying as water levels changed.

Description of Prior-Converted Cropland Study Sites. These sites are cultivated along with adjacent upland areas for row crop (primarily corn and/or soybean) production (figures 3 and 5). Soils and sediments near the prior-converted cropland sites reflect variable geologic, hydrologic, and geochemical conditions. Beneath cultivated uplands, soils were generally well-drained sandy loams, and shallow sediments were primarily sand and gravel with few fine textured layers and little organic matter. Sediment color was predominantly tan to orange or red, indicative of predominantly oxic soil and aquifer conditions. Soils beneath the wetland depressions, conversely, were generally poorly drained with abundant organic matter at the surface, but sandier and more permeable than those beneath the restored and natural wetlands. The fine textured sediments near the land surface in the prior-converted croplands were generally underlain by interbedded sand, gravel, silt, and clay that coarsened with depth. Coarse gravel commonly occurred at the base of the surficial aquifer above the underlying clay of the confining unit. At prior-converted cropland site 1 (PCC1), the surficial aquifer was 7 to $10 \mathrm{~m}$ (23 to $33 \mathrm{ft}$ ) thick, and tan and orange coarse sand and gravel at the base of the aquifer suggest that oxic groundwater occurs beneath overlying anoxic wetland sediments (figure $5 \mathrm{a}$ ). The surficial aquifer at prior-converted cropland site 2 (PCC2) was similar in thickness (about $8 \mathrm{~m}[26 \mathrm{ft}]$ ), but had gray sediments to the base of the surficial aquifer suggesting consistently anoxic conditions (figure $5 \mathrm{~b}$ ).

Artificial drainage supports cultivation at both prior-converted cropland sites (figures $3 \mathrm{c}$ and $3 \mathrm{~d}$ ). A water control structure was used to retain water in the ditch draining PCC1 and surrounding aquifer sediments. The ditch at PCC1 presumably received water only from the surrounding cropland. Conversely, the main ditch draining PCC2 receives water originating from upland and prior-converted cropland portions of an agricultural field to the north and a forested wetland complex to the south. These adjacent land cover types were separated by a free-flowing ditch which likely replaced a former stream channel.

Description of Restored Wetlands Study Sites. These sites include previous priorconverted sites that were returned to wetland hydrology through one of two USDA management practices to meet varying landowner preferences (figures 3 and 6). One of the restored sites (RES1) represents a USDA wetland restoration where both hydrologic and vegetative conditions were modified to closely resemble a natural wetland and garner a wide range or ecosystem service benefits (USDA NRCS 2010). The other restored site (RES2) was constructed according to the USDA NRCS Shallow Water Development and Management protocol for aesthetic purposes and to attract wildlife (USDA NRCS 2006b). The land surface depression at RES2 includes both the restored shallow water management area and an adjacent natural forested wetland (figure 3f). Soils and hydrology at the restored sites reflect previous drainage for agricultural use, as well as restoration to 


\section{Figure 4}

Cross sections of natural sites (a) NAT1 and (b) NAT2 showing the general configuration of the surficial aquifer and high and low water levels during 2008.

(a)

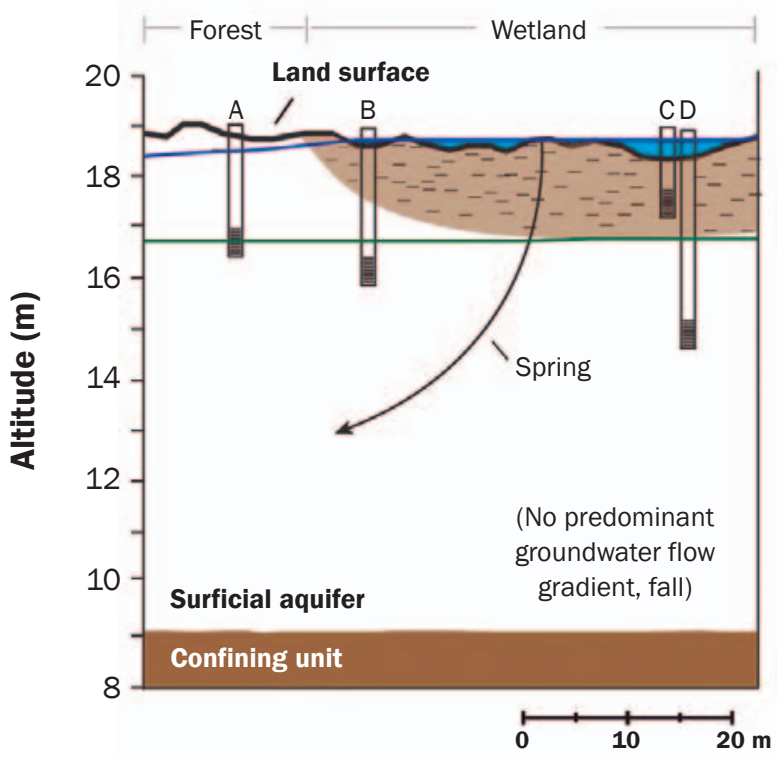

(b)

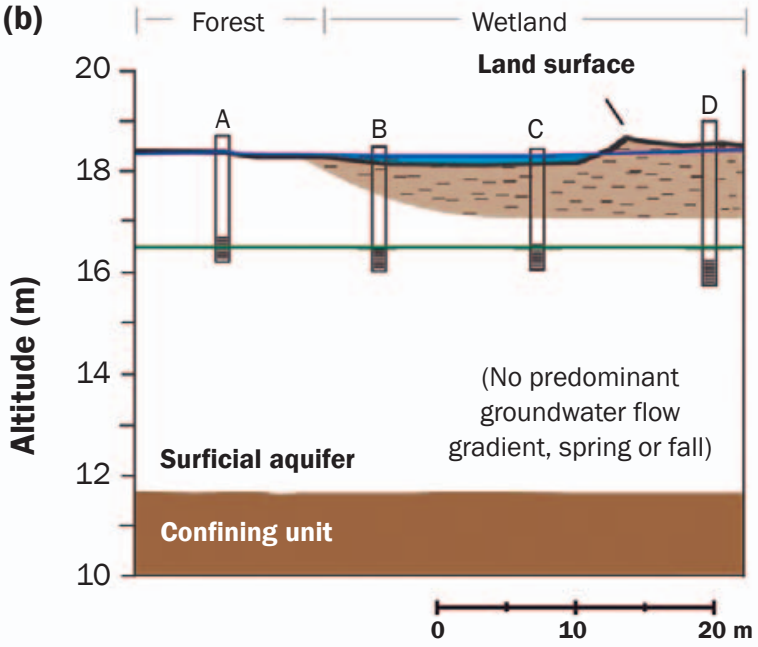

\section{Legend}

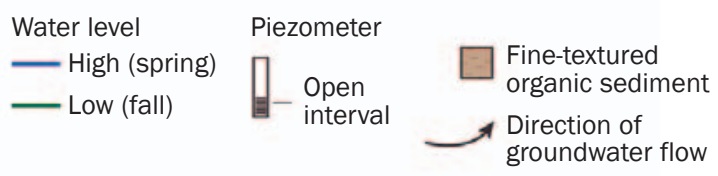

\section{Figure 5}

Cross sections of prior-converted cropland sites (a) $\mathrm{PCC} 1$ and (b) PCC2 showing the general configuration of the surficial aquifer and high and low water levels during 2008.

(a)

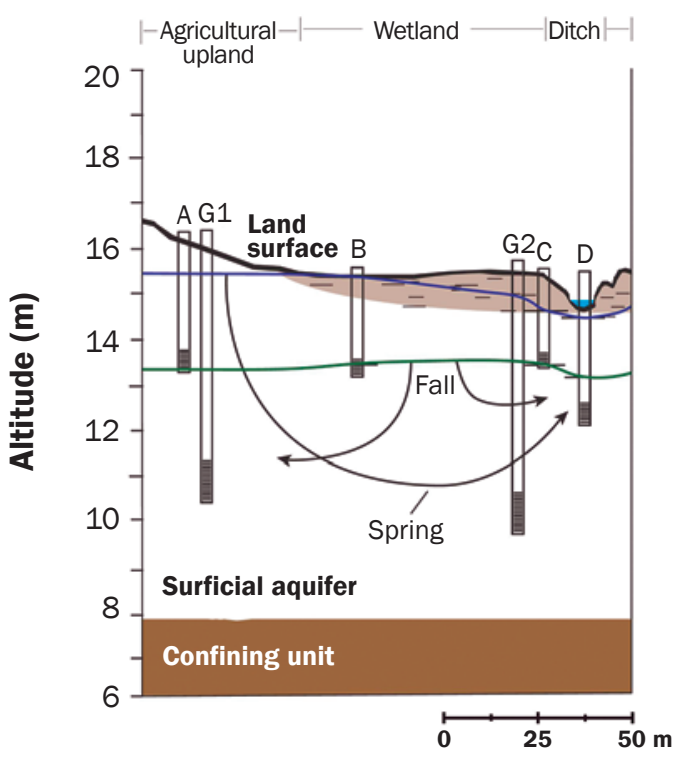

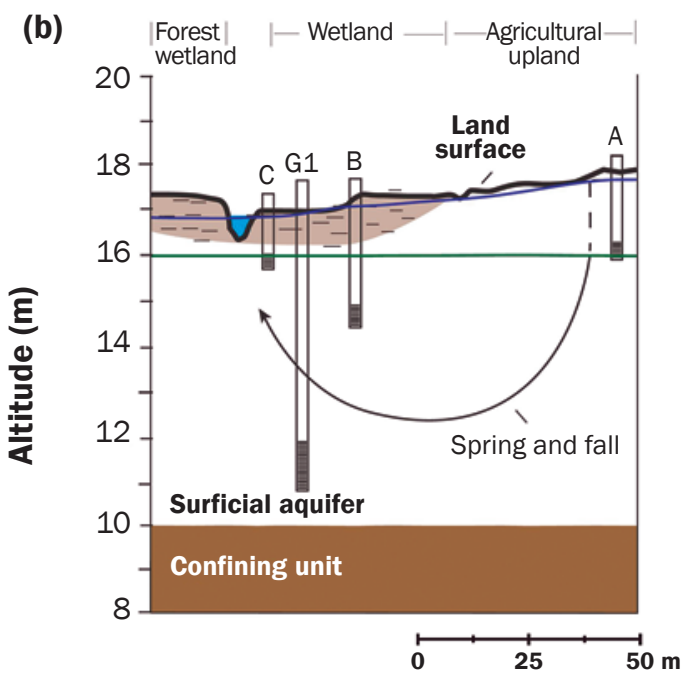

Legend

Water level

- High (spring)

— Low (fall)
Fine-textured organic sediment Direction of groundwater flow 


\section{Figure 6}

Cross sections of restored sites (a) RES1 and (b) RES2 showing the general configuration of the surficial aquifer and high and low water levels during 2008.

(a)

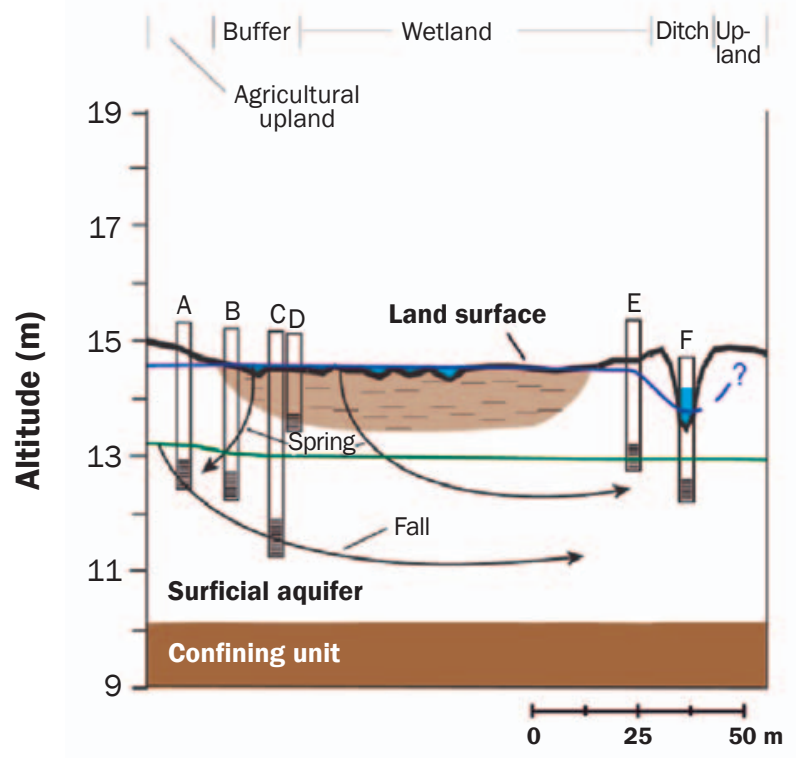

(b) $\begin{gathered}\text { Agricultural } \\ \text { upland }\end{gathered}-$ Buffer - Wetland - Forested

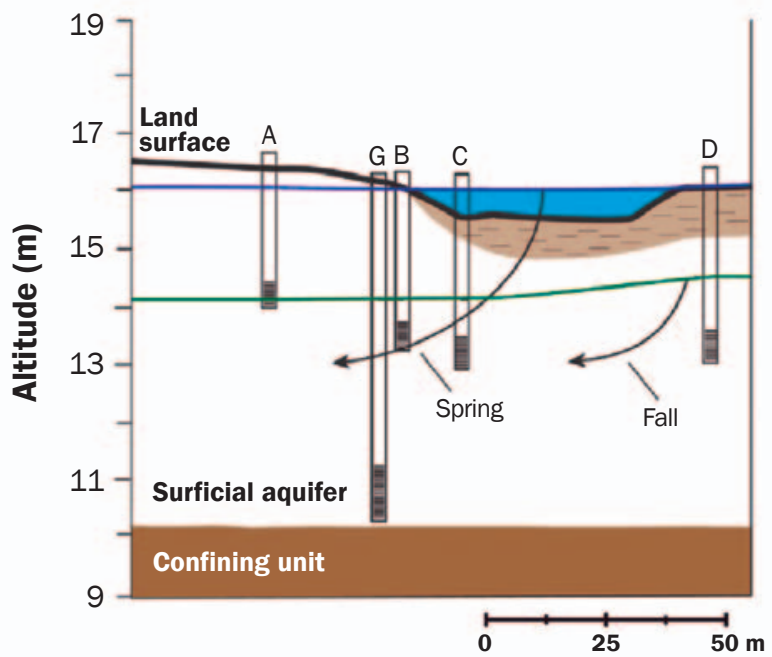

Legend

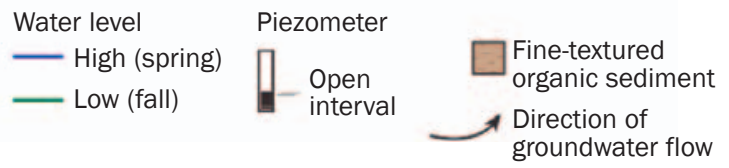

more closely approximate the more natural sites. Soils include well-drained sandy loams on uplands within agricultural fields, similar to prior-converted cropland sites, and very poorly drained organic mucks beneath the depressional wetlands, similar to natural sites (USDA NRCS 2006a). Surficial clay and/or silt layers from $0.5 \mathrm{~m}(1.6 \mathrm{ft})$ to more than $2 \mathrm{~m}(6.6 \mathrm{ft})$ in thickness present beneath the restored wetlands prolong ponding of surface water. To encourage inundation at RES2, the permeability of surficial sediments was further restricted by compaction during restoration.

Hydrologic and Geochemical Data Collection and Analysis. Hydrologic, geochemical, and water quality data were collected in and around each wetland study site. Data often lacking in previous wetland studies were collected, including deep cores of aquifer sediments, vertical as well as horizontal water-level gradients, and concentrations of major inorganic ions (including calcium [Ca], magnesium [Mg], sodium [Na], potassium $[\mathrm{K}]$, biocarbonate $\left[\mathrm{HCO}_{3}\right]$, sulfate $\left[\mathrm{SO}_{4}\right]$, and chloride $[\mathrm{Cl}]$ ) in groundwater and surface waters. These data were used to improve understanding of the configuration of groundwater movement through the shallow aquifer system and to characterize groundwater chemistry to enhance understanding of the potential for interception and removal of $\mathrm{NO}_{3}$.

Water-level data and water samples for nutrient and gas analyses were collected monthly at all sites in 2008. Figures and tables are primarily based on results from 2008 when all sites were sampled monthly to enable direct comparisons between the sites. Data collection continued at the prior-converted cropland and restored sites through 2009 at monthly or quarterly intervals, but was discontinued at the natural sites after 2008 because it was determined that agricultural chemicals were not intercepted at these sites. With the exception of some of the data from the two prior-converted cropland sites and some deep groundwater samples, the 2009 data are not included.

Data were collected to evaluate the local hydrology and potential for $\mathrm{NO}_{3}$ interception at each wetland study site. Shallow piezometers were installed in auger holes at selected soil sampling locations to support groundwater-level observations and groundwater sampling. Piezometers were constructed using $5 \mathrm{~cm}$ (2 in) PVC pipe with a 0.2 to $0.3 \mathrm{~m}(0.7$ to $1 \mathrm{ft})$ screened interval at the base; depths ranged from 0.5 to 4 $\mathrm{m}(1.6$ to $13 \mathrm{ft})$ beneath the ground surface. Piezometer installation during a particularly dry period from September of 2007 through November of 2007 maximized piezometer depth. Staff gauges were installed in wetland ponds and ditches to facilitate surface-water-level monitoring at five of the six sites. Piezometers and surface-water staff gauges at each site were surveyed to a common local datum determined from light detection and ranging (LiDAR) elevation mapping (Lang and McCarty 2009) to support comparisons of water levels to determine local water table gradients. Because the hand-augered piezometers were shallow relative to the thickness of the surficial aquifer, groundwater samples represented recent recharge to the water table in the vicinity of the piezometers and, therefore, geochemical processes affecting $\mathrm{NO}_{3}$ transport and transformation of groundwater moving through the wetlands and uplands at each site. Samples from these piezometer transects do not necessarily rep- 
resent transport of chemicals along a single groundwater flow path. Water samples were collected from deeper parts of the surficial aquifer at selected prior-converted cropland and restored wetland sites in March of 2009 using a Geoprobe, which uses pressure and percussion to advance a temporary well-point into the aquifer, to evaluate water chemistry at depths beneath the installed piezometers.

Water levels were measured, and water quality samples (including analyses of $\mathrm{NO}_{3}$ and excess nitrogen $\left[\mathrm{N}_{2}\right]$ gas) were collected to support interpretation of groundwater hydrology, associated nitrogen fate, and transport in and around each wetland. On the day prior to sampling, water levels were measured in each piezometer using an electric tape, and the piezometers were pumped dry and allowed to recover. Although some groundwater samples (excluding those for dissolved gases) were collected in April of 2008, March of 2009, and April of 2009 using a peristaltic pump, most samples were collected using a Teflon bailer equipped with one-way valves at both ends to minimize partial vacuum and atmospheric exposure of the freshly recharged groundwater. After filling the bailer with water from the bottom of the piezometer, a stopcock was added to the bottom of the bailer for distribution of groundwater from the bailer to sample tubes for dissolved gas analyses. The sample was transferred into ground glass stoppered tubes or tubes with rubber septa from the bottom of the tube and allowing approximately one volume of overflow to reduce air contact and eliminate bubbles. Replicate samples were collected from each piezometer and the tubes were stored on ice until analysis the next day. Following collection of dissolved gas samples, the bailer was used to collect an additional sample for chemical analysis of $\mathrm{NO}_{3}$ and determination of conductivity. The bailer was rinsed with distilled water between samples to minimize cross contamination. Surface-water samples for analysis of $\mathrm{NO}_{3}$ and conductivity were collected using single grab samples from ditches and wetland ponds when water was present. All water samples were placed on ice in coolers and returned to the laboratory for analyses.

Groundwater and stream samples were analyzed for selected major inorganic ions, $\mathrm{NO}_{3}$ and dissolved gases $\left(\mathrm{N}_{2}\right.$, oxygen $\left[\mathrm{O}_{2}\right]$, and argon [Ar]). Samples were analyzed for dissolved gases, specific conductance, and $\mathrm{NO}_{3}$, using methods described in Fisher et al. (2010). Conductivity corrected to $25^{\circ} \mathrm{C}$ $\left(77^{\circ} \mathrm{F}\right)$ was measured in these samples in the laboratory using a Yokogawa conductivity meter (model SC82). Water samples for $\mathrm{NO}_{3}$ analysis were passed through 0.45 $\mu \mathrm{m}\left(1.8 \times 10^{-5}\right.$ in) glass fiber filters and analyzed colorimetrically at the USDA Agricultural Research Service (ARS) facility in Beltsville, Maryland, using methods described by McCarty et al. (2008) and Sutton et al. (2010). Samples collected during April of 2008, March of 2009, and April of 2009 were also analyzed for inorganic ions and $\mathrm{NO}_{3}$ using inductively coupled plasma analysis for cations, ion chromatography for chloride and sulfate, and cadmium reduction-diazotization for $\mathrm{NO}_{3}$ at the US Geological Survey (USGS) National Water Quality Laboratory in Denver, Colorado, as described in Fishman (1993).

Dissolved gases in groundwater were measured at the University of Maryland Horn Point Laboratory using a Balzers model QMG420 quadrapole mass spectrometer with a membrane inlet (MIMS) following a protocol developed by Kana et al. (1994,1998, 2002) The ground-glass stoppered groundwater samples were temperature-equilibrated in a water bath approximating the observed groundwater temperature, along with deionized water standards equilibrated with air. A set of standards was analyzed at the beginning and end of each batch of three to six samples and atmospheric pressure was recorded to $0.01 \mathrm{~mm}(0.001 \mathrm{~cm})$ mercury $(\mathrm{Hg})$ each time standards were run. A small peristaltic pump pulled standards and samples through the membrane inlet, which permitted the diffusion of gases into the vacuum surrounding the membrane, and the sample gases were swept into the mass spectrometer detectors. Both samples and standards were run in quadruplicate, and the three (usually the last three) with the most stable $\mathrm{N}_{2} / \mathrm{Ar}$ were subsequently analyzed.

The raw data from the MIMS were analyzed in a spreadsheet template to compute groundwater recharge temperature, excess $\mathrm{N}_{2}$, and percentage saturation $\mathrm{O}_{2}$. The $\mathrm{Ar}$ and $\mathrm{N}_{2}$ data were initially corrected for dioxygenyl $\left(\mathrm{O}_{2}\right)$ scavenging (Kana et al. 1998), and then the drift-adjusted. Air calibration factor $(\mu \mathrm{V}$ $\mu \mathrm{M}^{-1}$ ) was determined for each sample using air standards run at the beginning and end of each sample batch. Concentrations of $\mathrm{Ar}$, $\mathrm{N}_{2}$, and $\mathrm{O}_{2}$ in the samples $(\mu \mathrm{M})$ were computed using sample signals $(\mu \mathrm{V})$ and the air calibration factors. Drift in the instrument calibration factors was time-corrected for each sample by linear extrapolation of the standards during the sample batch.

Argon concentrations were used as an inert, physical tracer of gas exchange between rain and the atmosphere prior to and during infiltration of rainwater to groundwater. An inverted solubility curve was used to estimate the effective recharge temperature from the measured Ar concentrations, and the recharge temperature was then used to estimate the background dissolved $\mathrm{N}_{2}, \mathrm{O}_{2}$, carbon dioxide $\left(\mathrm{CO}_{2}\right)$, nitrous oxide $\left(\mathrm{N}_{2} \mathrm{O}\right)$, and methane $\left(\mathrm{CH}_{4}\right)$ in equilibrium with atmospheric gases. The background dissolved gases were compared with the observed $\mathrm{N}_{2}$ and $\mathrm{O}_{2}$ measured in the MIMS. Excess $\mathrm{N}_{2}-\mathrm{N}$ and percentage saturation $\mathrm{O}_{2}$ were computed as: excess $\mathrm{N}_{2}-\mathrm{N}=2 \times\left(\right.$ observed $\mathrm{N}_{2}-$ equilib-
rium $\left.\mathrm{N}_{2}\right)$

percentage saturation $\mathrm{O}_{2}=100 \times$ (observed $\mathrm{O}_{2} \div$ equilibrium $\mathrm{O}_{2}$ ).

Excess $\mathrm{N}_{2}$ was expressed per unit $\mathrm{N}$ for comparison with $\mathrm{NO}_{3}$ as $\mathrm{N}\left(\mathrm{NO}_{3}-\mathrm{N}\right)$.

Excess $\mathrm{N}_{2}-\mathrm{N}$ represents the amount of inorganic $N$ (from denitrification) that has been converted to $\mathrm{N}_{2}$ gas in the groundwater. In contrast to supersaturated $\mathrm{N}_{2}$ in groundwater, $\mathrm{O}_{2}$ is usually undersaturated in groundwater and varies from near-zero to 90\% saturation.

Dissolved gas measurements were used to estimate loss of $\mathrm{NO}_{3}-\mathrm{N}$ through denitrification in groundwater using the methods described in Fisher et al. (2010) as follows. Effective groundwater recharge temperatures based on observed Ar concentrations were used to estimate background dissolved $\mathrm{N}_{2}-\mathrm{N}$ in equilibrium with the atmosphere prior to infiltration to groundwater. Observed $\mathrm{N}_{2}-\mathrm{N}$ in groundwater in excess of estimated atmospheric $\mathrm{N}_{2}-\mathrm{N}$ was assumed to be attributable to denitrification, and the sum of estimated excess $\mathrm{N}_{2}-\mathrm{N}$ and observed $\mathrm{NO}_{3}-\mathrm{N}$ concentrations represents an estimate of initial or reconstructed $\mathrm{NO}_{3}-\mathrm{N}$ concentrations prior to any loss through denitrification. Estimates of excess $\mathrm{N}_{2}-\mathrm{N}$ may be biased high, by dissolution of air bubbles trapped in soil during seasonal changes in groundwater levels or infiltration (Ingram et al. 2007). Other factors that can affect estimates of excess $\mathrm{N}_{2}-\mathrm{N}$ gas 
in groundwater include determination of the equilibrium recharge temperature (Böhlke 2002) and degassing in shallow sediments through $\mathrm{CH}_{4}$ or $\mathrm{N}_{2}$ ebullition, especially when the water table is at or near the land surface (Blicher-Mathiesen et al. 1998).

Rank transform ANOVA and Tukey tests $(\alpha=0.05)$ (Helsel and Hirsch 1992) were used to compare the distribution of continuous variables (chemical concentrations) in groundwater and surface water among samples from uplands and different wetland settings. Where data are referred to as "agricultural uplands," they include water samples from piezometers located in upland areas beneath the agricultural fields of the priorconverted cropland and restored sites.

\section{Results and Discussion}

Natural Wetlands. Water levels at the natural sites, NAT1 and NAT2, reached seasonal and study-period highs in March of 2008 to April of 2008, and standing water was present in the depressions through late spring (figure 4). The underlying fine-textured sediments in the depressions absorbed and retained water that collected in the wetlands from local runoff and direct precipitation onto the surface of the wetland for longer time periods than the surrounding upland sediments. This resulted in the formation of a groundwater mound beneath NAT1. Groundwater levels during 2008 were consistently higher beneath the wetland depression (as apparent in piezometers NAT1-B and NAT1-C) than beneath the adjacent upland (piezometer NAT1-A) (figure $7 \mathrm{a}$ ). In contrast, the water table gradient was nearly flat at NAT2 and at both natural sites during the summer, suggesting minimal lateral groundwater flow (figure 4). The land surface elevation of the wetland depressions at the natural sites and their respective water levels were generally higher than those at the prior-converted croplands or restored wetlands and their adjacent agricultural uplands (figures 7 and 8a).

The natural wetland sites were located near topographic divides in groundwater recharge areas and did not intercept surface water or groundwater carrying $\mathrm{N}$ from agricultural areas. Compared to groundwater beneath agricultural uplands and prior-converted croplands, groundwater beneath and adjacent to the natural wetlands had significantly lower specific conductance (figure $8 \mathrm{~b}$ ) and lower concentrations of major inorganic ions (figure 9). Surface water in ponds and groundwater beneath forested upland areas at these sites had the lowest concentrations of ions (the most dilute water), and groundwater beneath inundated portions of natural wetland sites had higher concentrations of ions (figures 4 and 9a; table 1). Upland groundwater adjacent to the natural wetland depressions typically had characteristics of unconfined groundwater that has not been affected by the addition of anthropogenic chemicals (referred to as "natural" water quality) on the Delmarva Peninsula, which has been defined as having specific conductance less than $60 \mu \mathrm{S} \mathrm{cm} \mathrm{cm}^{-1}$ and $\mathrm{Cl}$ and $\mathrm{NO}$ concentrations less than $7 \mathrm{mg} \mathrm{Cl}$ $\mathrm{L}^{-1}(7 \mathrm{ppm} \mathrm{Cl})$ and $0.4 \mathrm{mg} \mathrm{NO}_{3}-\mathrm{N} \mathrm{L} \mathrm{L}^{-1}(0.4$ ppm $\mathrm{NO}_{3}-\mathrm{N}$ ) respectively (Denver 1986; Hamilton el al. 1993). Higher concentrations of major ions in groundwater beneath the wetland depressions likely reflect evaporation of ponded water prior to infiltration; concentrations of $\mathrm{SO}_{4}$ (from mineralization of organic matter) and iron $(\mathrm{Fe})$ (indicative of anoxic conditions) were also higher in groundwater beneath natural wetland depressions than beneath adjacent uplands (table 1 and figure 9a). Water chemistry associated with the natural wetlands reflected precipitation modified by mineralization of organic matter and mineral dissolution, and sometimes, evaporation (Denver 1986). Because of this, they provided a baseline for interpreting water chemistry affected by the addition of agricultural chemicals in priorconverted croplands and restored wetlands.

Nitrate concentrations in groundwater from the natural sites were generally less than $0.1 \mathrm{mg} \mathrm{NO}_{3}-\mathrm{N} \mathrm{L}^{-1}$ (0.01 ppm $\mathrm{NO}_{3}-$ $\mathrm{N}$ ), although concentrations of excess $\mathrm{N}_{2}-\mathrm{N}$ gas were commonly higher than those of $\mathrm{NO}_{3}$ (table 1; figures $8 \mathrm{~d}$ and $8 \mathrm{e}$ ). The highest concentration of $\mathrm{NO}_{3}$ measured in groundwater at the these sites was less than $0.4 \mathrm{mg}$ $\mathrm{NO}_{3}-\mathrm{N} \mathrm{L}^{-1}\left(0.4\right.$ ppm $\left.\mathrm{NO}_{3}-\mathrm{N}\right)$; however, the median concentration of excess $\mathrm{N}_{2}$ gas was greater than $1 \mathrm{mg} \mathrm{N}_{2}-\mathrm{N} \mathrm{L}^{-1}\left(1 \mathrm{ppm} \mathrm{N}_{2}-\mathrm{N}\right.$ ) (table 1 and figure $8 \mathrm{e}$ ). Nitrogen compounds in groundwater beneath the natural depression in these wetlands were likely derived from soil organic matter and precipitation. Groundwater beneath and adjacent to natural wetlands was commonly reducing, with low dissolved $\mathrm{O}_{2}$ concentrations (table 1 and figure $8 \mathrm{c}$ ). Drying of wetland sediments, such as that which occurred in the summer of 2008 , however, would promote oxic conditions, as suggested by mottling in shallow wetland sediments. Any $\mathrm{NO}_{3}$ formed through mineralization of organic matter during such periods would be reduced to $\mathrm{N}_{2}$ during wet periods when soils resaturate.

Prior-Converted Croplands. The water table beneath the study sites, PCC1 and PCC2, was relatively high, sometimes reaching the land surface (e.g., spring of 2008), and ditches contained water (similar to natural wetland sites); however, groundwater did not inundate and form ponds in the wetlands (figure 10). Groundwater levels were below the base of the depressions and ditches from July of 2008 through December of 2008, and many shallow piezometers at the sites were dry at that time. Groundwater levels increased over the winter, after which the water table rose above the depth of the piezometers throughout the remainder of the study period (figures $7 \mathrm{~b}$ and 10 ). The water table gradient typically followed topography from uplands toward the prior-converted croplands and ditches (figures 5 and 10). However, the hydrologic gradient at PCC1 reversed from August of 2008 through April of 2009 (figure 10a). During this reversal, the elevation of surface-water in the wetlands and saturated wetland sediments was higher than in the adjacent uplands, and groundwater flow was away from the wetland toward the agricultural upland, which is contrary to assumptions about flow based on topography (figure 5a). Transient fluctuations in the water table gradient at PCC1 may have been due to management of water levels with the water control structure located in the farm ditch downgradient of the wetland, and/or the effect of a large regional drainage ditch located several hundred meters to the west (figure 3c). At PCC2, conversely, the water table gradient was consistently from the uplands toward the ditch as suggested by local topography (figures $5 \mathrm{~b}$ and $10 \mathrm{~b}$ ).

The prior-converted croplands received direct application of nutrients through synthetic fertilizer and manure, $\mathrm{N}$ fixation of soybean crops, and precipitation and runoff from surrounding uplands. Oxic groundwater was common beneath upland fields surrounding the depressions (figures $8 \mathrm{c}$ and 10 ; table 1). Water chemistry reflected agricultural influences similar to those observed elsewhere on the Delmarva Peninsula (Denver 1989; Debrewer et al. 2008) and the wider Coastal Plain (Ator 2008), including elevated concentrations of $\mathrm{Ca}, \mathrm{Mg}$, $\mathrm{NO}_{3}$, and $\mathrm{Cl}$, presumably from agricultural 


\section{Figure 7}

Hydrographs (a) NAT1, (b) PCC1, and (c) RES2 show representative groundwater and surface-water levels relative to mean sea level at one site of each type level during 2008. (d) shows the monthly rainfall totals from a nearby local gauge in the Choptank Watershed.

(a)

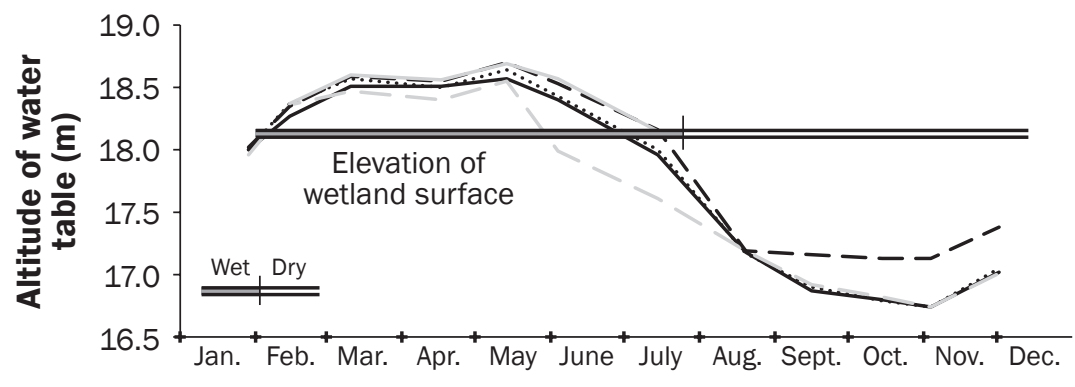

Legend

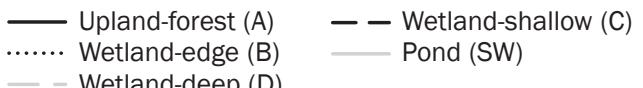

(b)

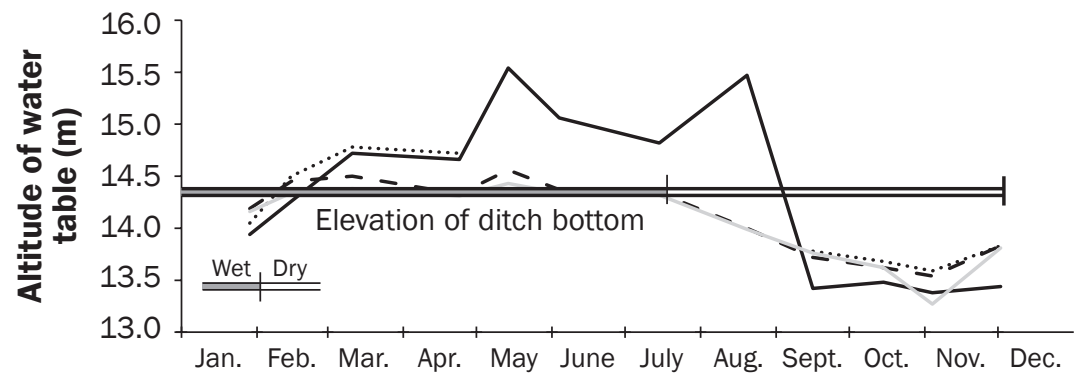

Legend

$\begin{array}{ll}\text { - Upland-ag }(\mathrm{A}) \quad \text { - } & \text { Ditch-edge }(\mathrm{C}) \\ \text { W.... Wetland-ag (B) } & \quad \text { Ditch (D) }\end{array}$

(c)

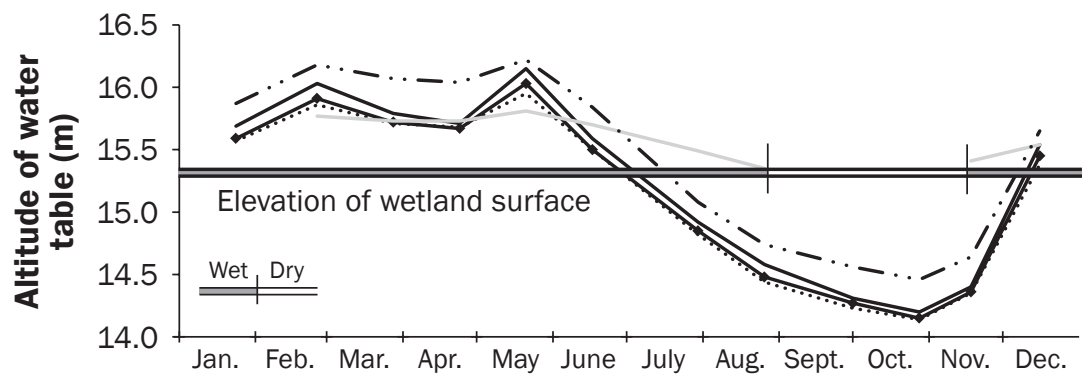

Legend

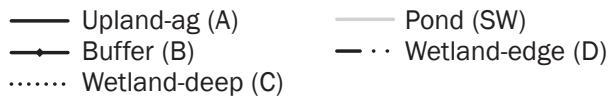

(d)

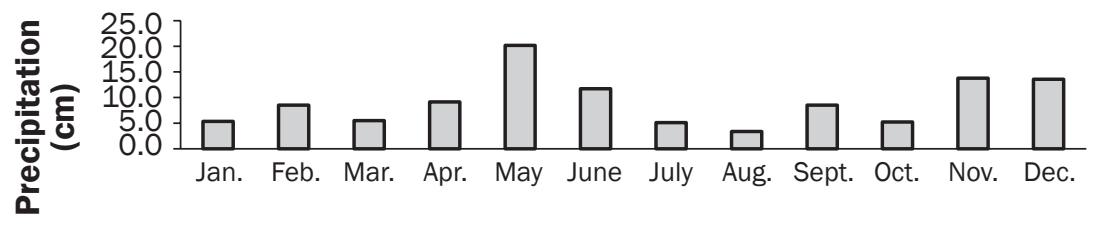

applications of lime, fertilizer, manure, and potash (figure 9b). Nitrate concentrations generally exceeded $10 \mathrm{mg} \mathrm{NO}{ }_{3}-\mathrm{N} \mathrm{L}^{-1}(10$ ppm $\mathrm{NO}_{3}-\mathrm{N}$ ) beneath agricultural uplands, and the addition of ions from agricultural sources resulted in the specific conductance of groundwater being elevated relative to the dilute baseline conditions seen in upland forested areas (figures $8 \mathrm{~b}$ and 9; table 1). Higher concentrations of $\mathrm{Cl}$ (from atmospheric sources) and $\mathrm{SO}_{4}$ (from atmospheric sources and produced through the degradation of organic matter) in groundwater beneath the prior-converted cropland instead of the uplands indicate that evaporation of water retained in wetland sediments affects the concentrations of these ions in groundwater (figure 9b).

Redox conditions, as indicated by dissolved $\mathrm{O}_{2}, \mathrm{NO}_{3}$, and excess $\mathrm{N}_{2}$ concentrations, varied spatially and temporally with wetting and drying cycles in groundwater within prior-converted croplands (figure 10). At both sites, excess $N_{2}$ concentrations decreased beginning in the late summer when water levels were low and wetland sediments were not saturated to the land surface. At PCC1, dissolved $\mathrm{O}_{2}$ increased in groundwater beneath the wetland during this period. Concentrations of dissolved $\mathrm{O}_{2}$ remained high and concentrations of excess $\mathrm{N}_{2}$ were low in groundwater beneath the agricultural uplands at both sites. Reconstructed $\mathrm{NO}_{3}$ concentrations (which represent the sum of $\mathrm{NO}_{3}-\mathrm{N}$ and excess $\mathrm{N}_{2}-\mathrm{N}$ ) that are lower than the concentration of $\mathrm{NO}_{3}$ beneath upland fields suggest that denitrification does not fully account for the differences in $\mathrm{NO}_{3}$ concentrations in groundwater beneath the historic wetlands and adjacent agricultural uplands at these sites (figure 8f). These differences may instead be related to addition of water from dilute, low $\mathrm{NO}_{3}$ runoff that collects in wetland depressions, or to degassing of $\mathrm{N}_{2}$ produced through denitrification in shallow wetland sediments. Data are not sufficient to determine which process is mainly responsible for differences in concentrations of reconstructed $\mathrm{NO}_{3}$ compared to $\mathrm{NO}_{3}$ in groundwater beneath the uplands.

The influence of PCC1 on the quality of groundwater from adjacent agricultural uplands is limited. Water chemistry in the drainage ditch at PCC1 reflected agricultural sources and denitrification, although observed groundwater redox conditions were variable, and $\mathrm{NO}_{3}$ was not completely 
Figure 8

Summary boxplots showing the range in (a) water levels, (b) specific conductance, and concentrations of (c) dissolved oxygen ( $\left.\mathrm{O}_{2}\right)$, (d) nitrate ( $\left.\mathrm{NO}_{3}\right)$, (e) excess nitrogen $(\mathrm{N})$, and $(\mathrm{f})$ reconstructed $\mathrm{NO}_{3}$ for piezometers and surface water at upper Choptank wetland study sites. Agricultural uplands (AUP) includes data from upland piezometers in PCC and RES sites. Prior-converted cropland (PCC) includes data from piezometers in PCC wetlands. Restored wetlands (RES) include data from piezometers in RES wetlands. Natural wetlands (NAT) include data from piezometers in NAT wetlands and Surface water samples (SUR) are from all sites.

(a)

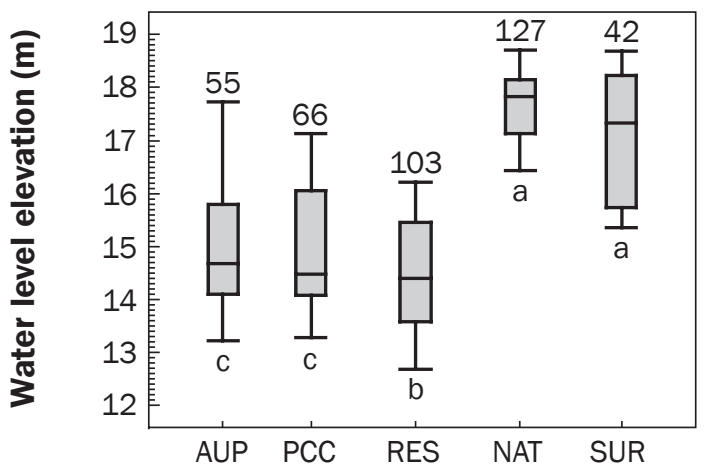

(c)

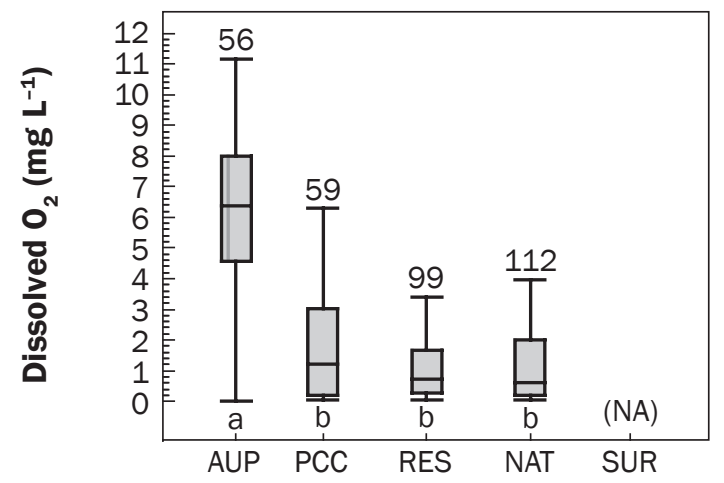

(e)

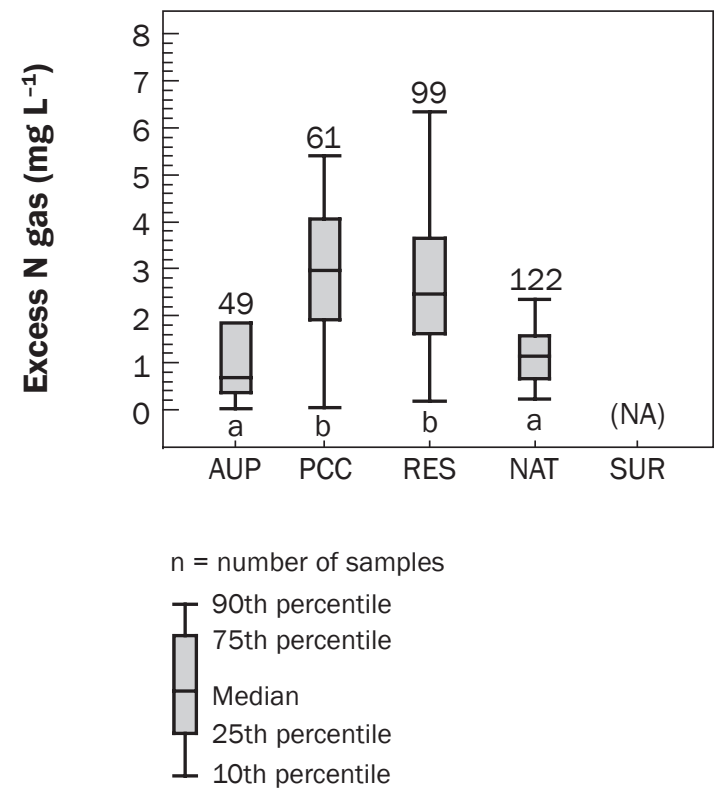

(b)

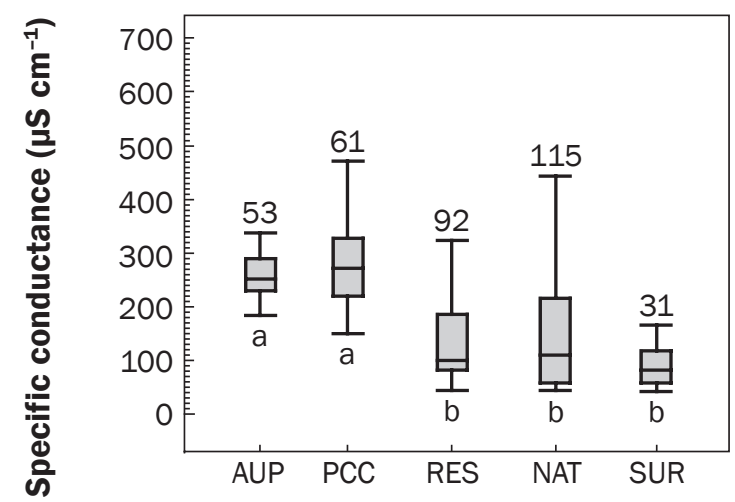

(d)

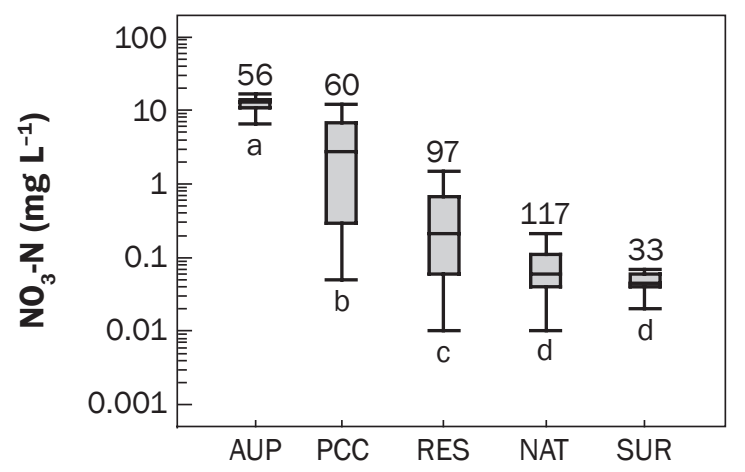

(f)

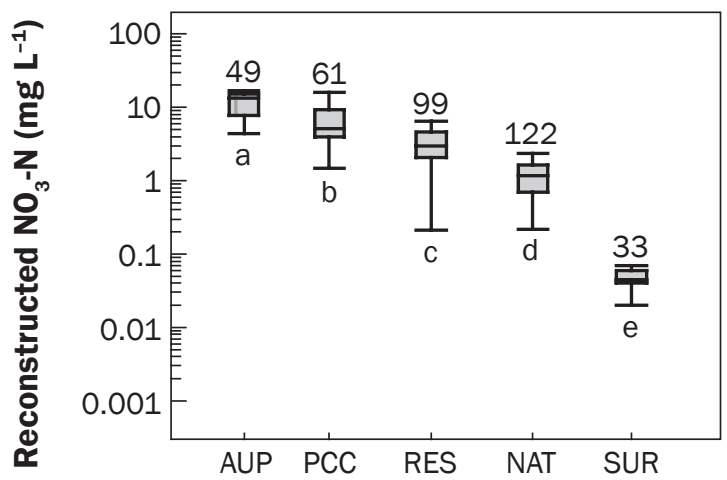

Note: a, b, c, d, e, beneath boxplots, indicate results of ANOVA and multiple comparison tests. Groups with same letter are not significantly different. 


\section{Figure 9}

Characteristics of the major-ion chemistry of water from different hydrologic settings associated with (a) natural, (b) prior-converted cropland, and (c) restored wetland sites. Each diagram represents the major-ion chemistry of a specific water sample. As the concentration of a particular ion increases, the diagram extends farther from the center axis. Smaller diagrams are associated with dilute water that represents relatively natural conditions in groundwater (such as in the forested wetland sample in NAT1) or water that is predominantly from rainfall (as in most surface water). Larger diagrams represent water with higher concentrations of ions commonly found in water that has additional ions from agricultural sources or evaporation.

(a)

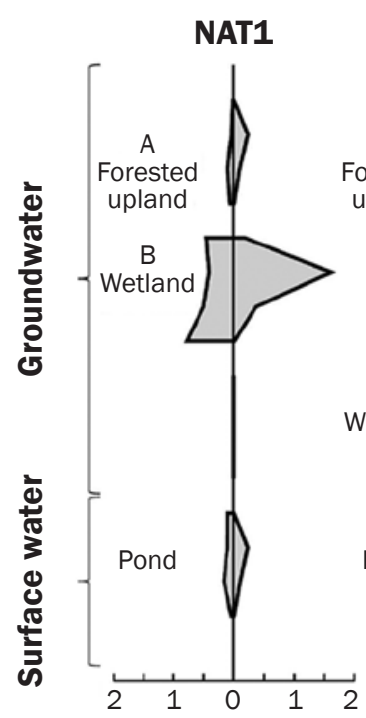

(b)

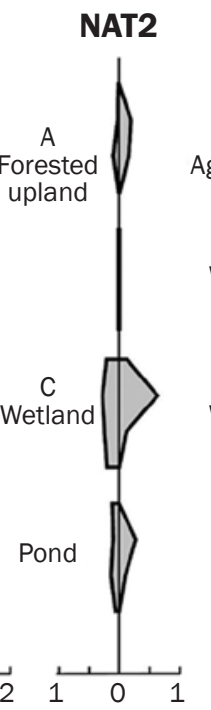

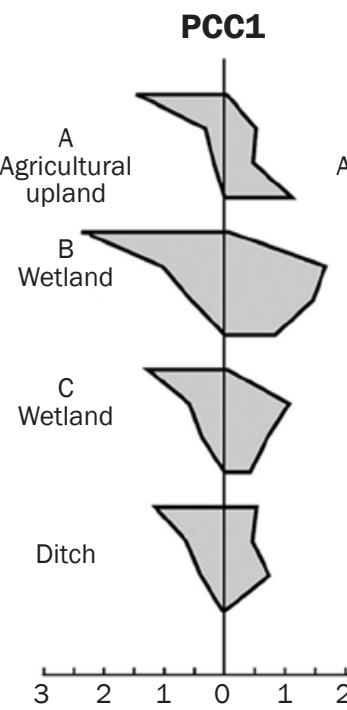

(c)
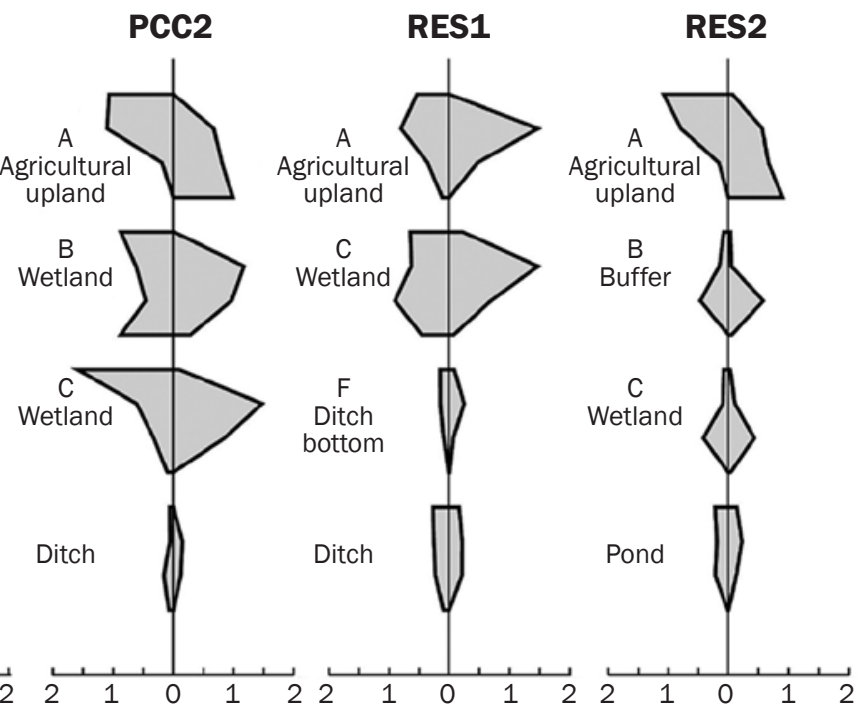

Concentration (mEq L-1)

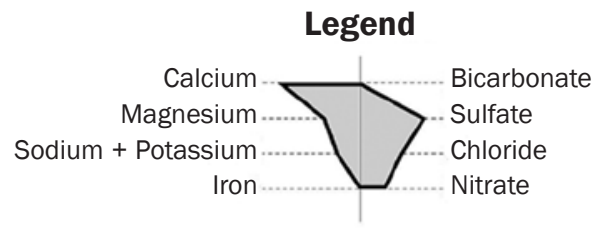

lost to denitrification (figures $9 \mathrm{~b}$ and 10 ; table 1). Regardless of the effectiveness of PCC1 wetland sediments at $\mathrm{NO}_{3}$ removal, however, our results indicate that hydrologic conditions were such that the PCC1 wetland received groundwater flow from a relatively limited area. During the dry period in the fall of 2008, groundwater underlying much of the depression at PCC1 flowed west toward a major regional drainage ditch rather than toward PCC1 (figure 5a). Furthermore, groundwater beneath the depression was oxic during that period with abundant $\mathrm{NO}_{3}$, suggesting that the vertical influence of denitrifying conditions on groundwater quality was limited at this site (figure 10a). Deeper water samples collected with a Geoprobe indicated that oxic groundwater containing $\mathrm{NO}_{3}$ was present at depth and may carry $\mathrm{NO}_{3}$ conservatively (without loss) beneath the wetland to downstream receiving waters (piezometers PCC1-G1 and PCC1-G2 on figure $5 \mathrm{a}$ and table 1$)$.

Hydrologic and geochemical conditions at PCC2 supported relatively effective removal of agricultural $\mathrm{NO}_{3}$ in groundwater. Unlike PCC1, the groundwater flow gradient at PCC2 was consistent from the agricultural upland toward the ditch, and anoxic conditions were observed throughout the thickness of the aquifer (figures $5 \mathrm{~b}$ and $10 \mathrm{~b}$; table 1). Groundwater chemistry at shallow and deeper depths beneath the wetland consequently reflected agricultural influences and denitrification (figure $10 \mathrm{~b}$ and table 1). Groundwater levels in the forested wetlands across the ditch from the PCC2 cropland were generally higher than in the PCC2 wetland. It is likely that this fact significantly slowed the rate of groundwater through PCC2 and influenced the presence of reducing conditions throughout the thickness of the surficial aquifer near and beneath the ditch. Even though groundwater flow from agricultural uplands adjacent to PCC2 was also from the upland toward the ditch, the chemistry of water in the ditch resembled that of the ponded water in natural wetlands (figure 9a), and not of denitrified groundwater from agricultural areas (figure 9b). The PCC2 wetland is apparently effective at reducing the overall flux of $\mathrm{N}$ that passes through wetland sediments to receiving surface waters (i.e., the ditch), but likely had relatively little effect on $\mathrm{N}$ concentrations leaving the site in surface water compared to the effect of flow from the much larger forested wetland complex adjacent to the ditch.

Restored Wetlands. Standing water was present in both restored wetland sites (RES1 and RES2) over much of the study period. The water table gradient was generally from the agricultural upland toward the adjacent 
Table 1

Summary of concentrations of selected chemical constituents in groundwater and surface water collected monthly during 2008 from the natural, prior-converted cropland, and restored depressional wetland study sites. Median measurements are provided, followed by minimum and maxium values in parentheses. Specific piezometer and surface-water site locations shown in figures 4, 5, and 6.

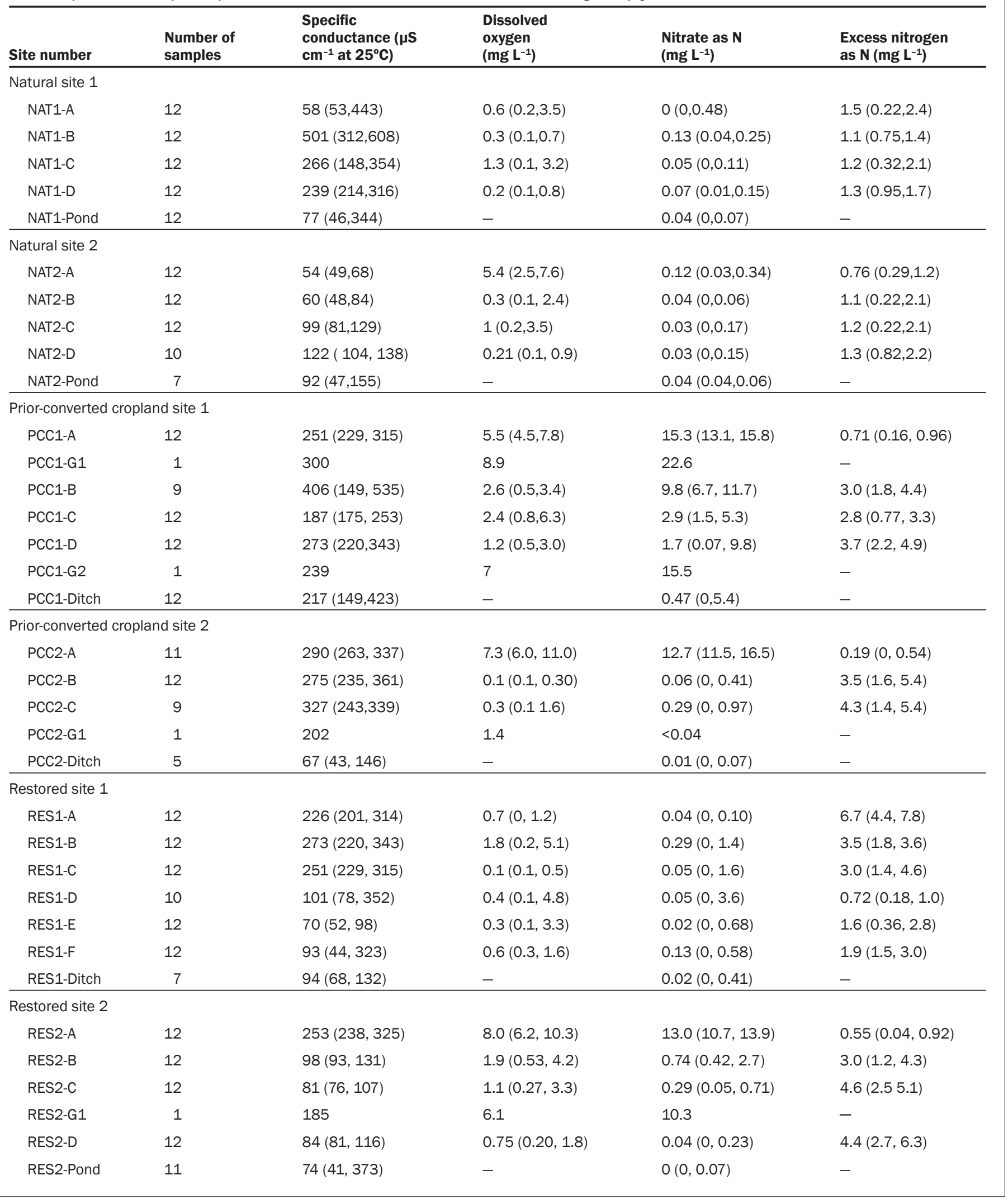


ditch at RES1 during much of the study period, with the hydraulic gradient apparently affected by the adjacent ditch down gradient of, but disconnected from, the wetland (figures $3 \mathrm{e}$ and $6 \mathrm{a}$ ). When the water table was highest in the spring, the water table was mounded beneath the wetland. At RES2, although the hydraulic gradient was toward the wetland conservation practice from the upland agricultural field, groundwater levels were highest throughout most of 2008 on the forested side of the depression, which is a natural depressional wetland (figures $3 f$, $7 \mathrm{c}$, and $6 \mathrm{~b}$ ). Waters absorbed in the organic matter and fine-textured sediments beneath the restored and natural wetlands maintain higher water levels and release water more slowly to adjacent surface-water bodies than waters absorbed in the coarser-textured sediments beneath prior-converted croplands. Water levels were commonly the highest beneath the wetlands at both restored sites.

Geochemical conditions suggest varying effects of RES1 and RES2 on agricultural $\mathrm{NO}_{3}$ in groundwater, as at the prior-converted cropland sites. Concentrations of dissolved oxygen in groundwater were lower than those in the prior-converted cropland sites and suggest that denitrification was more complete in restored wetlands than in prior-converted croplands (figure 8c). As in the prior-converted cropland sites, total reconstructed $\mathrm{NO}_{3}$ concentrations suggest wetland denitrification does not completely account for the decrease in $\mathrm{NO}_{3}$ concentrations found between the agricultural uplands and the restored wetlands (figures $8 \mathrm{~d}, 8 \mathrm{e}$, and $8 \mathrm{f}$ ). Because of the presence of a buffer between the wetlands and upgradient agriculture, water chemistry at RES2 was likely affected by chemicals from precipitation that recharges the water table through the buffer, degradation of organic matter in sediments of the buffer and the wetland, and interception of water from upgradient agriculture (figure 9c). Redox conditions in shallow groundwater beneath the wetlands were variable, but groundwater was most commonly anoxic (figures $8 \mathrm{c}$ and table 1). However, shallow groundwater at RES2 was oxic beneath the agricultural upland and at a depth beneath the wetland, as at PCC1 (figures $6 \mathrm{~b}$ and piezometer RES2-G1 on table 1).

Concentrations of $\mathrm{NO}_{3}$ in groundwater were consistently low at RES1, but evidence of denitrification of agricultural $\mathrm{NO}_{3}$ was found in water from the most upgra-

\section{Figure 10}

Water table elevations and concentrations of nitrate $\left(\mathrm{NO}_{3}-\mathrm{N}\right)$, dissolved oxygen $\left(\mathrm{O}_{2}\right)$, and excess $\mathrm{N}_{2}-\mathrm{N}$ gas in groundwater from upland and wetland piezometers at (a) PCC 1 and (b) PCC2.

(a)
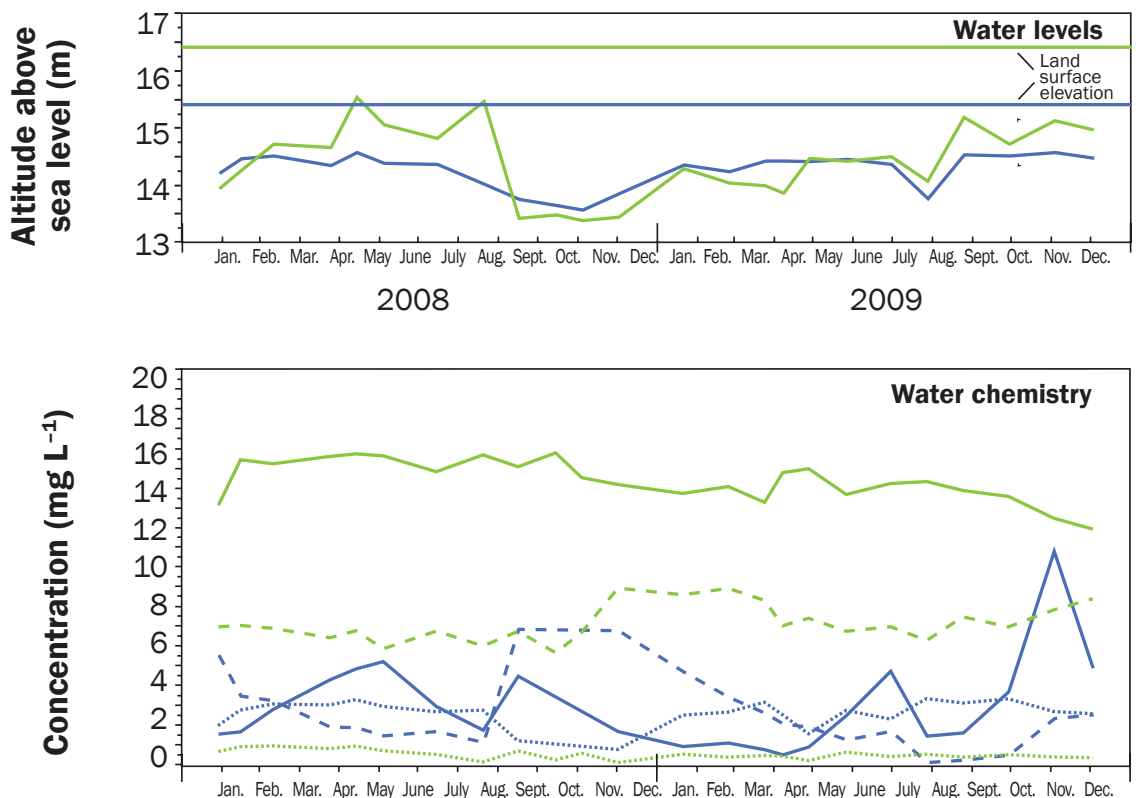

(b)

2008

2009
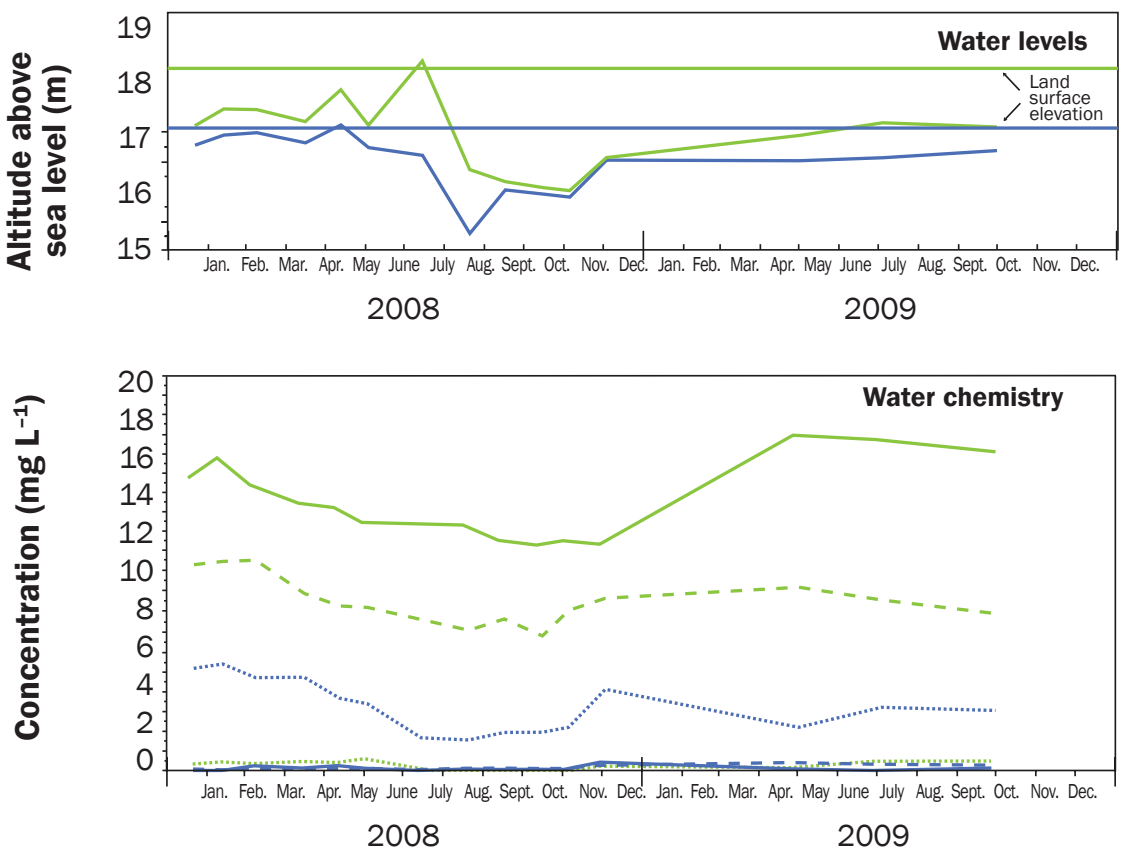

\section{Legend}

Piezometers

$\begin{array}{lllll}\text { Upland } & \text { Wetland }- & \mathrm{NO}_{3}-\mathrm{N} & - & \text { Dissolved } \mathrm{O}_{2} \\ \text { PCC1-A, PCC2-A } & \begin{array}{l}\text { PCC1-C, PCC2-C } \\ \text { Excess } \mathrm{N}_{2}-\mathrm{N}\end{array} & \ldots . . . & \end{array}$

PCC1-C, PCC2-C

Excess $\mathrm{N}_{2}-\mathrm{N} \quad \cdots \cdot$

dient piezometer (RES1-A) located at the interface between the upland and buffer, in particular, and, to a lesser extent, the adja- cent downgradient wetland piezometers (figure 6a and table 1). Denitrification was also indicated by concentrations of excess 
$\mathrm{N}_{2}$ gas that is greater in groundwater from these piezometers than is normally seen in a forested setting with low $\mathrm{N}$ inputs (figure $6 \mathrm{a}$ and table 1). Water chemistry from the piezometers located in the wetland near the ditch, and in the ditch bottom, more closely resembled water chemistry commonly seen in forested areas that are often considered to represent natural conditions, and did not appear to intercept significant water from an agricultural source (figure $6 \mathrm{a}$ and table 1). A similar pattern of higher concentrations of $\mathrm{Cl}$ and $\mathrm{SO}_{4}$ in groundwater beneath the restored wetland, as seen beneath the natural wetlands, might indicate evaporation has concentrated these chemicals in water (figure 9c). Water samples from the upland piezometer at this site are also reduced and exhibit similar water chemistry.

Water chemistry at RES2 indicates that the inundated wetland area has minimal impact on $\mathrm{NO}_{3}$ from upgradient agriculture (figure $6 \mathrm{a}$ andtable 1). Although groundwater beneath the wetland (piezometer RES2-C) and the buffer (piezometer RES2-B) contains $\mathrm{N}$ mostly in the form of excess $\mathrm{N}_{2}$, it does not resemble denitrified groundwater from agricultural areas such as in the upgradient piezometer, RES2-A (table 1). Rather, groundwater beneath the buffer and wetland (figure 9c; piezometers RES2-B and RES2-C) has lower specific conductance with higher $\mathrm{Na}$ and $\mathrm{Cl}$ concentrations than in water effected by agricultural chemicals, such as in the agricultural uplands at that site (piezometer RES2-A). Groundwater at depth beneath the wetland was oxic with abundant $\mathrm{NO}_{3}$, similar to that beneath upgradient agriculture (table 1, piezometer RES2-G1). This suggests that groundwater beneath the buffer and wetland likely recharged in the buffer rather than in upgradient agriculture. It also indicates that groundwater from upgradient agriculture likely carries $\mathrm{NO}_{3}$ beneath the wetland to downgradient discharge areas, as at PCC1 (figure 6b).

Implications for Study of Depressional Wetlands. Variability in $\mathrm{N}$ fate and transport around depressional wetlands in the upper Choptank illustrates the complexity of controlling geologic, hydrologic, and geochemical conditions in such settings and also demonstrates the critical need for improved understanding of these conditions when quantifying the effectiveness of depressional wetlands for $\mathrm{N}$ mitigation. Limited measurement of redox conditions and $\mathrm{N}$ species alone are insufficient to determine the full potential for or extent of interception and removal of $\mathrm{NO}_{3}$ from agricultural sources. Because groundwater is the primary vector for $\mathrm{N}$ movement in these systems, observations adequate for assessing multi-dimensional physical hydrology (e.g., groundwater head gradients throughout the thickness of the aquifer) are of primary importance. Limited water-level measurement at the water table along a presumed transect are rarely sufficient, considering groundwater rarely flows laterally just beneath the water table and decreasing heads along such a transect do not necessarily indicate that piezometers are sampling a common flow path. For example, water table mounding, common beneath upland depressional wetlands in the upper Choptank Watershed, significantly limits the interception of $\mathrm{NO}_{3}$ from adjacent agriculture and confounds estimation of groundwater flow based on surface topography. Also, where the surficial aquifer is sufficiently thick, groundwater may carry $\mathrm{NO}_{3}$ beneath wetland reducing conditions to downgradient discharge areas, as at PCC1 and RES2.

Measurements of broader geochemical indicators, such as major inorganic ions, in addition to $\mathrm{N}$ species can be useful for evaluating groundwater flow and the potential interception of water from agricultural sources. Concentrations of conservative ions not subject to redox conditions (e.g., $\mathrm{Cl}$ ) along with measurement of specific conductance, for example, can be used to demonstrate whether groundwater with low $\mathrm{NO}_{3}$ concentrations represents reduced groundwater from agriculture, as at PCC2 and RES1, or merely water that recharged through a forested or other nonagricultural area, as at RES2.

A few generalizations can be made regarding improvement of the effectiveness of wetland conservation practices and general wetland management for improving the mitigation of agricultural $\mathrm{NO}_{3}$. For example, the creation of a confining soil layer to encourage inundation, either through the application of fine-textured soils (i.e., clay) and/or the compaction of existing soil, often reduces the vertical extent of anoxic soils and may reduce the interaction of the wetland with $\mathrm{NO}_{3}$ in underlying groundwater (e.g., RES2). Although depressional wetlands with natural vegetation that are upgradient from croplands may not directly reduce agricultural $\mathrm{NO}_{3}$ within the wetland itself, they may do so indirectly by supporting the maintenance of anoxic sediments beneath adjacent ditches that also intercept agricultural chemicals in groundwater (e.g., PCC2). Therefore, the location of ditches between natural wetlands and agricultural fields may be an important tool for the reduction of agricultural $\mathrm{NO}_{3}$. In addition, drainage from these wetlands is an important source of water in local streams and may decrease surface-water concentrations of $\mathrm{NO}_{3}$ and other agricultural pollutants through mixing and dilution.

\section{Summary and Conclusions}

The effectiveness of depressional wetlands at mitigating agricultural $\mathrm{NO}_{3}$ in the upper Choptank Watershed is dependent primarily on hydrologic conditions that determine groundwater flowpaths and their interaction with geochemical conditions conducive to denitrification. Nitrate concentrations generally decreased along the anthropogenic alteration gradient from prior-converted cropland to restored to natural wetlands. This difference was not only due to a simple increase in denitrification of water with similar original $\mathrm{NO}_{3}$ concentrations from agricultural sources, but also to differences in the amounts of $\mathrm{NO}_{3}$ originally present in groundwater.

The forested natural wetlands studied have a high potential for denitrification but intercepted little or no agricultural $\mathrm{N}$ because of their location along water table divides in groundwater recharge areas. Natural wetlands may thus serve to improve regional water quality merely by acting as a source of low $\mathrm{NO}_{3}$ water to downstream surface waters, not by filtering nutrients from upland areas.

Unlike the natural wetlands, prior-converted croplands received direct input of $\mathrm{N}$ through agricultural practices. Local hydrologic condition affected the extent that these wetlands intercepted and reduced $\mathrm{NO}_{3}$ in groundwater. Interception of agricultural $\mathrm{NO}_{3}$ was restricted at one site where the zone of reducing conditions associated with the historic wetland did not extend to the base of the surficial aquifer. In this case, $\mathrm{NO}_{3}$ present in deeper groundwater beneath the wetland was not reduced. Reducing conditions extended though the entire thickness of the surficial aquifer beneath another prior-converted cropland site and supported more complete mitigation of $\mathrm{NO}_{3}$ from upgradient agriculture.

Restored wetlands in the upper Choptank Watershed generally maintained reducing conditions necessary for denitrification for longer periods than prior-converted 
croplands. As with prior-converted croplands, however, the overall effectiveness of restored wetlands varies with differences in their interception of $\mathrm{NO}_{3}$ from agriculture. Groundwater from upland agriculture was intercepted and effectively denitrified at the site that had been restored to represent natural wetland hydrologic and vegetative conditions. At the site restored using the shallow water management and development protocol, however, little or no agricultural $\mathrm{NO}_{3}$ was intercepted, and $\mathrm{NO}_{3}$ present in groundwater likely passed conservatively beneath the wetland to down gradient receiving waters.

Finally, because local topographic gradients in flat landscapes commonly do not predict groundwater flow pathways, an effort should be made to restore wetlands in locations that are low relative to broader-scale topographic gradients and are more likely to intercept upgradient groundwater containing $\mathrm{NO}_{3}$.

\section{Acknowledgements}

The authors would like to thank the property owners who graciously allowed us access to their properties for this study. Funding was provided by the Wetland Component of the USDA Natural Resources Conservation Service (NRCS), National Conservation Effects Assessment Project (CEAPWetlands), and augmented with partial support from the National Science Foundation (NSF 0919181). We would like to thank Diane Eckles and William Effland, USDA NRCS CEAP-Wetland Science Coordinators, retired and current, respectively, for their support of this project. Thanks are also given to the many people who assisted with project design, network installation, data collection and report preparation including: Owen McDonough, Robert Oesterling, Ken Staver, and Stuart Cawley of the University of Maryland at College Park; Walter Stracke of USDA ARS (retired); Deb Bringman, Michael Brownley, Frank Danner (retired), and Dan Phelan (retired), and Jessica Carpenter of USGS Maryland-Delaware-District of Columbia Water Science Center; and Robert Rossman of the USGS New Jersey Water Science Center.

\section{References}

Ator, S.W. 2008. Natural and human influences on water quality in a shallow regional unconsolidated aquifer, Northern Atlantic Coastal Plain. US Geological Survey Scientific Investigations report 2008-5190. Reston, VA: US Geological Survey.

Ator, S.W., and J.M. Denver. 2012. Estimating contributions of nitrate and herbicides from groundwater to headwater streams, Northern Atlantic Coastal Plain, United States. Journal of the American Water Resources Association doi:10.1111/j.175201688.2012.00672.x.
Ator, S.W., J.M. Denver, and M.J. Brayton. 2005a. Hydrologic and geochemical controls on pesticide and nutrient transport to two streams on the Delmarva Peninsula. US Geological Survey Scientific Investigations Report 2004-5051. Reston,VA: US Geological Survey.

Ator, S.W., J.M. Denver, D.E. Krantz, W.L. Newell, and S.K. Martucci. 2005b. A surficial hydrogeologic framework for the Mid-Atlantic Coastal Plain. US Geological Survey Professional Paper 1680. Reston, VA: US Geological Survey.

Bachman, L.J., B.D. Lindsey, J.W. Brakebill, and D.S. Powars. 1998. Groundwater discharge and base-flow nitrate loads of non-tidal streams, and their relation to a hydrogeomorphic classification of the Chesapeake Bay Watershed, Middle Atlantic Coast. US Geological Survey Water-Resources Investigations Report 98-4059. Baltimore, MD: US Geological Survey.

Blicher-Mathiesen, G., G.W. McCarty, and L.P. Neilsen. 1998. Denitrification and degassing in groundwater estimated from dissolved dinitrogen and argon. Journal of Hydrology 208:16-24.

Böhlke, J.K. 2002. Groundwater recharge and agricultural contamination. Hydrogeology Journal 10:153-179.

Böhlke, J.K., and J.M. Denver. 1995. Combined use of groundwater dating, chemical, and isotopic analyses to resolve the history and fate of nitrate contamination in two agricultural watersheds, Atlantic Coastal Plain, Maryland. Water Resources Research 31(9):2319-2339.

Böhlke, J.K., M.E. O'Connell, and K.L. Prestegaard. 2007. Ground water stratification and delivery of nitrate to an incised stream under varying flow conditions. Journal of Environmental Quality 36:664-680

Brakebill, J.W., and S.D. Preston. 2004. Digital data used to relate nutrient inputs to water quality in the Chesapeake Bay Watershed, Version 3.0. US Geological Survey Open-File Report 2004-1433. Baltimore, MD: US Geological Survey.

Debrewer, L.M., S.W. Ator, and J.M. Denver. 2008. Temporal trends in nitrate and selected pesticides in Mid-Atlantic ground water. Journal of Environmental Quality 37:S296-S308.

Denver, J.M. 1989. Effects of agricultural practices and septicsystem effluent on the quality of water in the unconfined aquifer in parts of eastern Sussex County, Delaware. Delaware Geological Survey Report of Investigations No. 45. Newark, DE: University of Delaware.

Denver, J.M. 1986. Hydrogeology and geochemistry of the unconfined aquifer, west-central and southwestern Delaware. Delaware Geological Survey Report of Investigations No. 41. Newark, DE: University of Delaware.

Denver, J.M., A. J. Tesoriero, and J.R. Barbaro. 2010. Trends and transformation of nutrients and pesticides in a Coastal Plain aquifer system, United States. Journal of Environmental Quality 39(1):154-167.

Dunkle, S.A., L.N. Plummer, E. Busenberg, P.J. Phillips, J.M. Denver, P.A. Hamilton, R.L. Michel, and T.B. Coplen. 1993. Chlorofluorocarbons (CCl3F and CCL2F2) as dating tools and hydrologic tracers in shallow ground water of the Delmarva Peninsula, Atlantic Coastal Plain, United States. Water Resources Research 29(12): 3827-3860.

Fisher, T.R., K.Y. Lee, H. Berndt, J.A. Benitez, and M.M. Norton. 1998. Hydrology and chemistry of the Choptank River basin in the Chesapeake Bay drainage. Water, Air, \& Soil Pollution 105:387-397.

Fisher, T.R., J.D. Hagy III, W.R. Boynton, and M.R. Williams. 2006. Cultural eutrophication in the Choptank and Patuxent estuaries of Chesapeake Bay. Limnology and Oceanography 51:435-447.

Fisher, T.R., T.E. Jordan, K.W. Staver, A.B. Gustafson, A.I. Koskelo, R.J. Fox, A.J. Sutton, T. Kana, K.A. Beckert, J.P. Stone, G.W. McCarty, and M.W. Lang. 2010. The Choptank Basin in transition: Intensifying agriculture, slow urbanization, and estuarine eutrophication. In Coastal Lagoons: Systems of Natural and Anthropogenic Change, eds. M.J. Kennish and H.W. Paerl, 135-165. Boca Raton, FL: CRC Press.

Fishman, M.J. 1993. Methods of analysis by the U.S. Geological Survey National Water Quality LaboratoryDetermination of inorganic and organic constituents in water and fluvial sediments. U.S. Geological Survey OpenFile Report 93-125. Reston,VA: US Geological Survey.

Hamilton, P.A., J.M. Denver, P.J. Phillips, and R.J. Shedlock. 1993. Water-quality assessment of the Delmarva Peninsula, Delaware, Maryland, and Virginia-Effects of agricultural activities on, and the distribution of, nitrate and other inorganic constituents in the surficial aquifer. U.S. Geological Survey Open-File Report 93-40. Reston,VA: US Geological Survey.

Helsel, D.R., and R.M. Hirsch. 1992. Statistical Methods in Water RFesources. Amsterdam: Elsevier Publishers.

Hill, A.R. 1996. Nitrogen removal in stream riparian zones. Journal of Environmental Quality 25(4):743-755.

Hirsch, R.M., D.L. Moyer, and S.A. Archfield. 2010. Weighted regressions on time, discharge, and season (WRTDS) with an application to Chesapeake Bay river inputs. Journal of the American Water Resources Association 46(5):857-880.

Howarth, R.W., G. Billen, D. Swaney, A. Townsend, N. Jaworski, K. Lajtha, J.A. Downing, R. Elmgren, N. Caraco, T. Jordan, F. Berendse, J. Freney, V. Kudeyarov, P. Murdoch, and Z. Zhao-liang. 1996. Regional nitrogen budgets and riverine $\mathrm{N} \& \mathrm{P}$ fluxes for the drainages of the North Atlantic Ocean: Natural and human influences. Biogeochemistry 35:75-139.

Ingram, R.G.S., K.M. Hiscock, and P.F. Dennis. 2007. Noble gas excess air applied to distinguish groundwater recharge conditions. Environmental Science and Technology 41:1949-1955.

Kana, T.M., C. Darkangelo, M.D. Hunt, J.B. Oldham, G.E. Bennett, and J.C. Cornwell. 1994. Membrane inlet mass spectrometer for rapid high-precision determination of $\mathrm{N}_{2}, \mathrm{O}_{2}$, and $\mathrm{Ar}$ in environmental water samples. Analytical Chemistry 66:4166-4170. 
Kana, T.M., M.B. Sullivan, J.C. Cornwell, and K.M. Groszkowski. 1998. Denitrification in estuarine sediments determined by membrane inlet mass spectrometry. Limnology and Oceanography 43:334-339.

Kana, T.M., and D.L. Weiss. 2004. Comment on "Comparison of isotope pairing and $\mathrm{N}_{2}$ :Ar methods for measuring sediment denitrification" by B.D. Eyre, S. Rysgaard, T. Dalsgaard, and P.B. Christianson. Estuaries 27(1):177-178.

Kennedy, C.D., D.P. Genereux, D.R. Corbett, and H. Mitasova. 2009. Spatial and temporal dynamics of coupled groundwater and nitrogen fluxes through a streambed in an agricultural watershed. Water Resources Research 45(9):W09401 doi:10.1029/2008WR007397.

Kirchner, W.N., B.A. Kleiss, E.J. Clairain Jr., W.B. Parker, and C.J. Newling. 1992. Delineation of wetland in the Yazoo River Basin in northwestern Mississippi US Army Corporation of Engineers. Miscellaneous Paper EL-92-2.

Lang, M.W., and G.W. McCarty. 2009. LiDAR intensity for improved detection of inundation below the forest canopy. Wetlands 29(4):1166-1178.

Lang, M.W., O. McDonough, G.W. McCarty, R. Oesterling, and B. Wilen. 2012. Enhanced detection of wetland-stream connectivity using LiDAR. Wetlands 32(3):461-473.

Leibowitz, S.G., and T. Nadeau. 2003. Isolated wetlands: State-of-the-science and future directions. Wetlands 23(3):663-684.

Mehnert, E., H.H. Hwang, T.M. Johnson, R.A. Sanford,W.C. Beaumont, and T.R. Holm. 2007. Denitrification in the shallow groundwater of a tile-drained, agricultural watershed. Journal of Environmental Quality 36(1):80-90.

McCarty, G.W., L.L. McConnell, C.J. Hapernan, A. Sadeghi, C. Graff, W.D. Hively, M.W. Lang, T.R. Fisher, T. Jordan, C.P. Rice, E.E. Codling, D. Whitall, A. Lynn, J. Keppler and M.L. Fogel. 2008. Water quality and conservation practice effects in the Choptank River watershed. Journal of Soil and Water Conservation 63(6):461-474, doi:10.2489/jswc.63.6.461.

Newell, W.L., and B.D. Dejong. 2011. Cold-climate slope deposits and landscape modifications of the MidAtlantic Coastal Plain, Eastern USA. Special Publications v. 354, 259-276. Piccadilly, London: Geological Society of London.

Nolan B.T., and K.J. Hitt. 2006. Vulnerability of shallow groundwater and drinking-water wells to nitrate in the United States. Environmental Science and Technology 40:7834-7840.

Owens, J.P., and J.P. Minard. 1979. Upper cenozoic sediments of the lower Delaware Valley and northern Delmarva Peninsula, New Jersey, Pennsylvania, Delaware, and Maryland. US Geological Survey Professional Paper 1067-D. Reston,VA: US Geological Survey.

Phillips, P.J., J.M. Denver, R.J. Shedlock, and P.A. Hamilton. 1993. Effect of forested wetlands on nitrate concentrations in ground water and surface water on the Delmarva Peninsula. Wetlands 13(2):75-83.

Phillips, S.W., and B.D. Lindsey. 2003. The influence of groundwater on nitrogen delivery to the Chesapeake Bay. US Geological Survey FS-091-03. Reston, VA: US Geological Survey.

Phillips, P.J., and R.J. Shedlock. 1993. Hydrology and chemistry of ground water and seasonal ponds in the Atlantic coastal plain in Delaware, USA. Journal of Hydrology 141:157-178.

Puckett, L.J. 2004. Hydrogeologic controls on the transport and fate of nitrate in groundwater beneath riparian buffer zones: Results from thirteen studies across the United States. Water Science and Technology 49(3):47-53.

Shedlock, R.J., J.M. Denver, M.A. Hayes, P.A. Hamilton, M.T. Koterba, L.J. Bachman, P.J. Phillips, and W.S.L. Banks. 1999. Water-quality assessment of the Delmarva Peninsula-Delaware, Maryland, and Virginia-Results of investigations, 1987-91. US Geological Survey WaterSupply Paper 2355-A. Reston,VA: US Geological Survey. Shedlock, R.J., P.A. Hamilton, J.M. Denver, and P.J. Phillips. 2003. Multiscale approach to regional ground-waterquality assessment of the Delmarva Peninsula. In Regional Ground-Water Quality, ed. W.M. Alley. New York, NY:Van Nostrand Reinhold.

Sprague, L.A., M.J. Langland, S.E. Yochum, R.E. Edwards, J.D. Blomquist, S.W. Phillips, G.W. Shenk, and S.D. Preston. 2000. Factors affecting nutrient trends in major rivers of the Chesapeake Bay Watershed. US Geological Survey Water-Resources Investigations Report 00-4218. Baltimore, MD: US Geological Society.

Spruill, T.B., A.J. Tesoriero, H.E. Mew Jr., K.M. Farrell, S.L. Harden, A.B. Colosimo, and S.R. Kraemer. 2005. Geochemistry and characterization of nitrogen transport at a confined animal feeding operation in a Coastal Plain agricultural watershed, and implications for nutrient loading in the Neuse River Basin, North Carolina, 1999-2002. US Geological Survey Scientific Investigations Report 2004-5283. Reston, VA: US Geological Survey.

Spruill,T.B., and J.E. Bratton. 2008. Estimation of groundwater and nutrient fluxes to the Neuse River Estuary, North Carolina. Estuaries and Coasts 31:501-520.

Staver, K.W., and R.B. Brinsfield. 1996. Groundwater nitrate seepage into the Wye River Estuary from a riparian agroecosystem. Estuaries 19(2B)359-370.

Sutton, A. J., T.R. Fisher, and A.B. Gustafson. 2010. Effects of restored stream buffers (CREP) on water quality in non-tidal streams in the Choptank River basin. Water, Air, \& Soil Pollution 208:101-118 doi10.1007/ s11270-009-0152-3.

Tesoriero, A.J., H. Leibscher, and S.E. Cox. 2000. Mechanisms and rate of denitrification in an agricultural watershedElectron and mass balance along ground-water flow paths. Water Resources Research 36(6):1545-1559.

Tesoriero, A.J., J.H. Duff, D.M. Wolock, N.E. Spahr, and J.E. Almendinger. 2009. Identifying pathways and processes affecting nitrate and orthophosphate inputs to streams in agricultural watersheds. Journal of Environmental Quality 38(5):1892-1900.

USDA NRCS (Natural Resources Conservation Service). 2006. Digital general soil map of US. http:// soildatamart.nrcs.usda.gov/.

USDA NRCS. 2006. Maryland conservation practice standard, Shallow water development and management, Code 646. http://efotg.sc.egov.usda.gov/references/ public/MW/MD646_06.pdf.

USDA NRCS. 2010. Conservation practice standard, Wetland restoration, Code 657. ftp://ftp-fc.sc.egov. usda.gov/NHQ/practice-standards/standards/657.pdf.

Whigham, D.F., and T.E. Jordan. 2003. Isolated wetlands and water quality. Wetlands 23(3):541-549.

Winter, T.C. 1983. The interaction of lakes with variably saturated porous media. Water Resources Research 19(5):1283.

Winter, T.C. 1999. Relation of streams, lakes, and wetlands to groundwater flow systems. Hydrogeology Journal $7: 28-45$. 